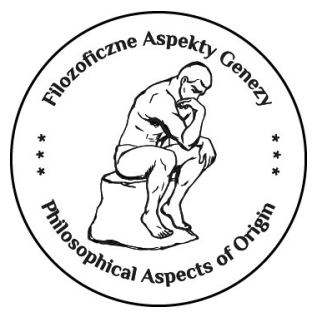

Filozoficzne Aspekty Genezy — 2019/2020, t. 16/17

Philosophical Aspects of Origin

\title{
Dwustronna przyczynowość i rozszerzona synteza ewolucyjna
}

\section{Wprowadzenie}

W ciągu minionych 40 lat rozmaici badacze krytykowali strukturę teorii ewolucji w jej aspekcie przyczynowym. ${ }^{1}$ Ta linia krytyki została rozwinięta na nowe sposoby przez zespół Kevina Lalanda. Argumenty jego zespołu przykuły dużą uwagę, zwłaszcza osób opowiadających się za utworzeniem nowej ewolucjonistycznej ramy pojęciowej, którą nazwano rozszerzoną syntezą ewolucyjną (EES - extended evolutionary synthesis). ${ }^{2}$ EES to tylko jedna $\mathrm{z}$ wielu najnowszych prób stworzenia nowej ewolucjo-

AndRew Buskell, Pн.D. — University of Cambridge, St John's College, e-mail: ab2086@cam.ac.uk.

"Andrew Buskell, „Reciprocal Causation and the Extended Evolutionary Synthesis”, Biological Theory 2019, vol. 14, s. 267-279, https://link.springer.com/content/pdf/10.1007/s13752-019-00325-7.pdf [10. 09.2020]. Z języka angielskiego przełożył Dariusz SAGAN.

${ }^{1}$ Por. np. Richard Levins and Richard Lewontin, The Dialectical Biologist, Harvard University Press, Cambridge 1985; Paul E. Griffiths and Russell D. Gray, „Developmental Systems and Evolutionary Explanation", The Journal of Philosophy 1994, vol. 91, no. 6, s. 277-304; Susan Oyama, The Ontogeny of Information: Developmental Systems and Evolution, Duke University Press, Durham 2000; Stephen Jay Gould, The Structure of Evolutionary Theory, Harvard University Press, Cambridge 2002.

${ }^{2}$ Por. np. Kevin N. Laland, Tobias Uller, Marcus W. Feldman, Kim Sterelny, Gerd B. Müller et al., „Does Evolutionary Theory Need a Rethink? Yes, Urgently”, Nature 2014, vol. 514, s. 161-164; Kevin N. Laland, Tobias Uller, Marcus W. Feldman, Kim Sterelny, Gerd B. Müller et al., „The Extended Evolutionary Synthesis: Its Structure, Assumptions and Predictions", Proceedings of the Royal Society B: Biological Sciences 2015, vol. 282, no. 1813, numer artykułu: 20151019; Kevin N. LaLand, John OdLingSmeE, and John Endler, „Niche Construction, Sources of Selection and Trait Coevolution”, Interface Focus 2017, vol. 7, no. 5, numer artykułu: 20160147; Kevin N. LaLAND, „On Evolutionary Causes and Evolutionary Processes", Behavioural Processes 2015, vol. 117, s. 97-104. 
nistycznej ramy pojęciowej, ${ }^{3}$ ale szybko uzyskała główną rolę w dyskusjach na ten temat. Istnieje już sporo publikacji, w których EES albo brana jest za podstawę, ${ }^{4}$ albo jest krytykowana. ${ }^{5}$

Kluczowym zagadnieniem z perspektywy krytyków EES jest to, czy powszechna praktyka (consensus pratice) w ramach obecnej teorii ewolucji wystarczy do wyjaśnienia zjawisk ewolucyjnych. Idąc śladem Philipa Kitchera, ${ }^{6}$ termin powszechna praktyka odnoszę do trwałych i współdzielonych praktyk w jakimś obszarze nauki, które ustanawiają typowe podejścia do prowadzenia badań, określają istotność i znaczenie pytań

${ }^{3}$ Por. np. Rudolf A. RafF, The Shape of Life: Genes, Development, and the Evolution of Animal Form, University of Chicago Press, Chicago 1996; Jason Scott RoBert, Embryology, Epigenesis, and Evolution: Taking Development Seriously, Cambridge University Press, Cambridge 2004; Sean B. Carroll, Endless Forms Most Beautiful: The New Science of Evo Devo, Norton, New York 2005; Sean B. CArroll, „Evo-Devo and an Expanding Evolutionary Synthesis: A Genetic Theory of Morphological Evolution”, Cell 2008, vol. 134, no. 1, s. 25-36; Gerd B. MülLer, „Evo-Devo: Extending the Evolutionary Synthesis”, Nature Reviews Genetics 2007, vol. 8, no. 12, s. 943-949; Gerd B. MüLler, „Dlaczego rozszerzona synteza ewolucyjna jest niezbędna”, przeł. Dariusz Sagan, Filozoficzne Aspekty Genezy 2018, t. 15, s. 371-413, http://www.nauka-a-religia.uz.zgora.pl/images/FAG/2018.t.15/art.08.pdf [14.09.2020]; Massimo Pigliucci, „Do We Need an Extended Evolutionary Synthesis?”, Evolution 2007, vol. 61, no. 12, s. 2743-2749; Massimo Pigliucci, „An Extended Synthesis for Evolutionary Biology”, Annals of the New York Academy of Sciences 2009, vol. 1168, s. 218-228; Massimo PigliucCI and Gerd B. MülLeR, „Elements of an Extended Evolutionary Synthesis", w: Massimo PigliucCI and Gerd B. Müller (eds.), Evolution: The Extended Synthesis, MIT Press, Cambridge 2010, s. 3-17.

${ }^{4}$ Por. np. Alex Mesoudi, Simon Blanchet, Anne Charmantier, Étienne Danchin, Laurel Fogarty, Eva Jablonka, Kevin N. Laland, Thomas J.H. Morgan, Gerd B. Müller, F. John Odling-Smee, and Benoît Pusol, „Is Non-Genetic Inheritance Just a Proximate Mechanism? A Corroboration of the Extended Evolutionary Synthesis”, Biological Theory 2013, vol. 7, no. 3, s. 189-195; Agustin Fuentes, „The Extended Evolutionary Synthesis, Ethnography, and the Human Niche: Toward an Integrated Anthropology", Current Anthropology 2016, vol. 57, Supplement 13, s. S13-S26; Dolores R. PIPERno, „Assessing Elements of an Extended Evolutionary Synthesis for Plant Domestication and Agricultural Origin Research", Proceedings of the National Academy of Sciences USA 2017, vol. 114, no. 25, s. 6429-6437; Melinda A. Zeder, „Domestication as a Model System for the Extended Evolutionary Synthesis”, Interface Focus 2017, vol. 7, numer artykułu: 20160133, https ://doi.org/10.1098/rsfs.2016.0133; Qiaoying Lu and Pierrick BourRat, "The Evolutionary Gene and the Extended Evolutionary Synthesis", British Journal for the Philosophy of Science 2018, vol. 69, no. 3, s. 775-800; Tobias Uller and Heikki Helanterä, „Niche Construction and Conceptual Change in Evolutionary Biology”, British Journal for the Philosophy of Science 2019, vol. 70, no. 2 , s. 351-375.

${ }^{5}$ Por. np. Thomas E. Dickins and Qazi Rahman, „The Extended Evolutionary Synthesis and the Role of Soft Inheritance in Evolution”, Proceedings of the Royal Society B: Biological Sciences 2012, vol. 279, no. 1740, s. 2913-2921; Thomas E. Dickins and Robert A. BArTon, „Reciprocal Causation and the Proximate-Ultimate Distinction”, Biology \& Philosophy 2013, vol. 28, no. 5, s. 747-756; Brett CALcotT, „Why How and Why Aren't Enough: More Problems with Mayr's Proximate-Ultimate Distinction", Biology \& Philosophy 2013, vol. 28, no. 5, s. 767-780; Gregory A. Wray, Hopi E. Hoekstra, Douglas J. Futuyma, Richard E. LensKI, Trudi F.C. Mackay et al., „Does Evolutionary Theory Need a Rethink? No, All Is Well", Nature 2014, vol. 514, s. 161-164; Deborah Charlesworth, Nicholas H. Barton, and Brian Charlesworth, „The Sources of Adaptive Variation”, Proceedings of the Royal Society B: Biological Sciences 2017, vol. 284, numer artykułu: 20162864; John J. WeLCH, „What's Wrong with Evolutionary Biol- 
badawczych oraz wyznaczają standardy oceniania rywalizujących wyjaśnień. Takie współdzielone praktyki są wpajane badaczom w trakcie kształcenia, szkolenia i bezpośredniego doświadczenia w stosowaniu ewolucjonistycznego typu rozumowania. Chociaż taki proces wpajania jest najprawdopodobniej wysoce zindywidualizowany, to jego przybliżeniem może być struktura i prezentacja teorii ewolucji w standardowych podręcznikach. $^{7}$

Jedna z ważnych cech argumentacji EES dotyczy ogólnej integracji teorii ewolucji z perspektywy powszechnej praktyki. Taka integracja może być w mniejszym lub większym stopniu scentralizowana albo eklektyczna ${ }^{8}$ Różnica zależy od stopnia, w jakim powszechna praktyka skupiona jest wokół centralnego teoretycznego, pojęciowego i metodologicznego jądra. W im większym stopniu powszechna praktyka skupia się wokół centralnego i dobrze zintegrowanego zbioru modeli, teorii, założeń i standardów wyjaśniania, tym bardziej scentralizowana i ,jądrowa” jest jej organizacja. Kiedy natomiast mamy do czynienia z luźną składanką metod badawczych i kryteriów eksplanacyjnych, być może służących wielu różnym zbiorom celów badawczych, to organizacja powszechnej praktyki jest bardziej eklektyczna.

Ogólnie rzecz biorąc, zwolennicy EES argumentowali, że powszechna praktyka jest scentralizowana, a tym samym mamy do czynienia z jej ,jądrową" organizacją. Przekonują więc, że „podstawowe założenia”, ${ }^{9}$ „główne zasady” ${ }^{10}$ czy „,podstawowa logika" ${ }^{11}$ musi zostać zaktualizowana i zmieniona. ${ }^{12}$ Innymi słowy, zwolennicy EES

ogy?", Biology \& Philosophy 2017, vol. 32, no. 2, s. 263-279.

${ }^{6}$ Por. Philip Kitcher, The Advancement of Science: Science Without Legend, Objectivity Without Illusions, Oxford University Press, Oxford 1993.

${ }^{7}$ Por. np. Douglas J. Futuyma and Mark KirkPatrick, Evolution, 4th ed., Oxford University Press, Oxford 2017; Alan C. Love, „Rethinking the Structure of Evolutionary Theory for an Extended Synthesis”, w: Pigliucci and Müller (eds.), Evolution: The Extended Synthesis..., s. 403-442.

${ }^{8}$ Por. Tim Lewens, Cultural Evolution: Conceptual Challenges, Oxford University Press, Oxford 2015.

${ }^{9}$ Laland, Uller, Feldman, Sterelny, Müller et al., „The Extended Evolutionary Synthesis...”.

${ }^{10}$ Pigliucci and Gerd B. Müller, „Elements of an Extended Evolutionary Synthesis...”, s. 4.

${ }^{11}$ MüLLER, „Dlaczego rozszerzona synteza ewolucyjna jest niezbędna...”, s. 400.

${ }^{12}$ Alan Love krytykuje jednak reprezentacje struktury teorii ewolucji sugerowane przez użycie słowa ,jądro” [(przyp. thum.) w oryginale stosowane są słowa „,core”, „core assumptions” i „core logic”, które nie wszystkie da się sensownie przełożyć przy użycia słowa ,,jądro” lub jego odmian]. Por. Love, „Rethinking the Structure of Evolutionary Theory for an Extended Synthesis...”; Alan C. Love, „Theory Is as Theory Does: Scientific Practice and Theory Structure in Biology”, Biological Theory 2013, vol. 7, no. 4, s. 325-337; Alan C. Love, „Evo-Devo and the Structure of Evolutionary Theory”, w: Philippe Huneman and Denis Walsh (eds.), Challenging the Modern Synthesis: Adaptation, Development, and Inheritance, Oxford University Press, Oxford 2017, s. 159-187. 
są optymistami: uważają, że nowe narzędzia, modele i koncepcje rozszerzą jądro teorii ewolucji za sprawą dokonania metodologicznej i pojęciowej korekty. Przeciwnicy EES (również ogólnie rzecz biorąc) są sceptykami: utrzymują, że powszechna praktyka ma się dobrze i że zjawiska stanowiące bodziec dla argumentów optymistów - a przynajmniej dziedziczenie inkluzyjne, tendencyjność rozwojowa i plastyczność fenotypowa — nie istnieją albo co najwyżej są marginalne, dobrze już zrozumiane oraz znajdują się w zasięgu standardowych modeli ewolucyjnych i tak dalej. Sceptycy zaprzeczają więc temu, że badania w ramach EES podważają lub radykalnie zmieniają współdzielone jądro powszechnej praktyki.

Aby rzucić nieco światła na te sprzeczne ze sobą oceny EES, przeanalizuję jedną z głównych idei optymistów: koncepcję dwustronnej przyczynowości (reciprocal causation). ${ }^{13}$ Koncepcja dwustronnej przyczynowości stanowi „definiujący” i „unifikujący” temat EES. W zamyśle ma ona podważać założenia przyczynowe wbudowane w modelach i wyjaśnieniach formułowanych $\mathrm{w}$ ramach powszechnej praktyki. Nie jest jednak jasne, jaka jest pozytywna epistemiczna wartość tej koncepcji, o czym przekonamy się, rozważając zbiór konkurencyjnych interpretacji. ${ }^{14}$

W świetle tych różnic interpretacyjnych głównym zadaniem tego artykułu jest identyfikacja i objaśnienie: zinterpretowanie i staranne odróżnienie tych punktów, w których na podstawie pozytywnej epistemicznej wartości koncepcji dwustronnej przyczynowości można argumentować na rzecz zmian w powszechnej praktyce. Poniżej przedstawiam trzy takie argumenty. Mimo że wspieram się cytatami i argumentami zwolenników EES i jej interpretatorów, te linie argumentacji nie zostały w pełni wyartykułowane przez tych pierwszych. Moje rozważania najlepiej więc pojmować jako ekstrapolacje lub interpretacje — potencjalne sposoby, w jakie można wykorzystać koncepcję dwustronnej przyczynowości w argumentacji na rzecz EES.

\footnotetext{
${ }^{13}$ Por. Kevin N. Laland, Kim Sterelny, John Odling-Smee, William Hoppitt, and Tobias Uller, „Cause and Effect in Biology Revisited: Is Mayr's Proximate-Ultimate Dichotomy Still Useful?”, Science 2011, vol. 334, no. 6062, s. 1512-1516; Kevin N. Laland, John Odling-Smee, William Hoppitt, and Tobias Uller, „More on How and Why: Cause and Effect in Biology Revisited”, Biology \& Philosophy 2013, vol. 28, no. 5, s. 719-745; Kevin N. Laland, John Odling-Smee, William Hoppitt, and Tobias Uller, „More on How and Why: A Response to Commentaries", Biology \& Philosophy 2013, vol. 28, no. 5, s. 793-810; Laland, Uller, Feldman, Sterelny, Müller et al., „The Extended Evolutionary Synthesis...”; Laland, „On Evolutionary Causes and Evolutionary Processes...".

${ }^{14}$ Por. CAlcott, „,Why How and Why Aren't Enough...”; Dickins and BArton, „Reciprocal Causation and the Proximate-Ultimate Distinction...”; Maximiliano Martínez and Maurizio Esposito, „Multilevel Causation and the Extended Synthesis", Biological Theory 2014, vol. 9, no. 2, s. 209-220; Richard A. Watson, Rob Mills, C.L. Buckley, Kostas Kouvaris, Adam Jackson, Simon T. Powers, Chris Cox, Simon Tudge, Adam Davies, Loizos Kounios, and Daniel Power, „Evolutionary Connectionism: Algorithmic Principles Underlying the Evolution of Biological Organisation in Evo-Devo, Evo-Eco and Evolutionary Transitions”, Evolutionary Biology 2016, vol. 43, no. 4, s. 553-581; Erik I. Svensson, „On Reciprocal Causation in the Evolutionary Process", Evolutionary Biology 2018, vol. 45, no. 1, s. 1-14.
} 
Ta egzegetyczna i ewaluacyjna strategia ma istotne znaczenie. W miarę, jak rozwijała się dialektyka między optymistami a sceptykami EES, coraz częściej pojawiały się głosy, że jedna strona nie rozumie drugiej. ${ }^{15}$ Należy pominąc retorykę i wyodrębnić potencjalne korzyści płynące z EES, sprawdzić, czy jej twierdzenia poparte są argumentami i pod jakimi względami koncepcje i metody nowej syntezy wyłamują się z empirycznego, pojęciowego i teoretycznego ujęcia aktualnej powszechnej praktyki.

\section{Dwustronna przyczynowość}

Czym jest dwustronna przyczynowość? W moim przekonaniu badacze EES używają tej koncepcji na dwa sposoby. Pierwszy to bezpośredni sens przyczynowy. W tym sensie dwustronna przyczynowość jest rodzajem związku przyczynowego, w którym dwa procesy wywierają na siebie wzajemny wpływ. ${ }^{16} \mathrm{~W}$ wielu publikacjach tylko tyle mają na myśli optymiści EES, kiedy odwołują się do tej koncepcji. Zespół Lalanda stwierdził: „Termin «dwustronna przyczynowość» oznacza po prostu, że proces $A$ jest przyczyną procesu $B$, a następnie proces $B$ jest przyczyną procesu $A$, przy czym to sprzężenie zwrotne może powtarzać się w łańcuchach przyczynowych". ${ }^{17}$ Chociaż szczegóły takiego wzajemnego wpływu przyczynowego mogą w poszczególnych przypadkach być różne, podstawowa idea jest prosta: dwa procesy przyczynowe są dwustronnie ze sobą powiązane o tyle, o ile są procesami sprzężonymi, a więc stan jednego procesu jest funkcją procesu drugiego (i na odwrót).

W tym ujęciu dwustronne procesy przyczynowe odróżniają się od procesów jednokierunkowych, czyli od związków przyczynowych, w których wzajemne wpływy są zaniedbywalne lub w ogóle nie występują. Przy takim sformułowaniu przyczynowość jednokierunkowa charakteryzuje wiele znanych przypadków przyczynowości: kamie-

\footnotetext{
${ }^{15}$ Por. np. żarliwą wymianę zdań między zespołem Manana Gupty a zespołem Marcusa Feldmana: Manan Gupta, N.G. Prasad, Sutirth Dey, Amitabh Joshi, and T.N.C. Vidya, „Niche Construction in Evolutionary Theory: The Construction of an Academic Niche?", Journal of Genetics 2017, vol. 96, no. 3, s. 491-504; Manan Gupta, N.G. Prasad, Sutirth Dey, Amitabh Joshi, and T.N.C. Vidya, „Feldman et al. Do Protest Too Much, We Think", Journal of Genetics 2017, vol. 96, no. 3, s. 509-511; Marcus W. Feldman, John Oduing-Smee, Kevin N. Laland, „Why Gupta et al. 's Critique of Niche Construction Theory Is Off Target”, Journal of Genetics 2017, vol. 96, no. 3, s. 505-508. Bardziej stonowana konfrontacja miała miejsce między zespołem Kevina Lalanda a zespołem Gregory'ego Wraya: Laland, Uller, Feldman, Sterelny, Müller et al., „Does Evolutionary Theory Need a Rethink...”; Wray, Hoekstra, Futuyma, Lenski, Mackay et al., „Does Evolutionary Theory Need a Rethink...”.

${ }^{16}$ Por. Laland, Sterelny, Odling-Smee, Hoppitt, and Uller, „Cause and Effect in Biology Revisited...”; Laland, Odling-Smee, Hoppitt, and Uller, „More on How and Why: Cause and Effect in Biology Revisited...”; Mesoudi, Blanchet, Charmantier, Danchin, Fogarty, Jablonka, Laland, Morgan, Müller, Odling-Smee, and Pujol, „Is Non-Genetic Inheritance Just a Proximate Mechanism...”.

${ }^{17}$ Laland, Uller, Feldman, Sterelny, Müller et al., „The Extended Evolutionary Synthesis...”, s. 6.
} 
nie spadają na ziemię, kule bilardowe zderzają się ze sobą, a promieniowanie słoneczne ogrzewa naszą planetę. Mówiąc ogólniej, przyczynowość jednokierunkowa charakteryzuje sytuacje, w których występują asymetryczne związki między przyczynami a skutkami. Posługując się terminologią Jamesa Woodwarda ${ }^{18}$ można powiedzieć, że istnieją sytuacje, w których żadne znaczące wpływy nie ulegają sprzężeniu zwrotnemu od zmienionego skutku do następującej później zmiany w przyczynie.

Badacze reprezentujący nauki o życiu są zaznajomieni z tym sformułowaniem pojęcia dwustronnej przyczynowości. Taki związek przyczynowy występuje w przypadku niekontrolowanego doboru płciowego, dodatniego i ujemnego, zależnego od częstości doboru w genetyce populacyjnej, diagramów sieci genów w ewolucyjnej biologii rozwoju oraz złożonych interakcji metabolizmu komórkowego. W tych i innych obszarach badacze tworzą modele sprzężonych procesów wzajemnego oddziaływania między elementami.

Zwolennicy EES posługują się jednak koncepcją dwustronnej przyczynowości również w bardziej rzeczowy sposób, często traktując ją jako kluczowy składnik zrewidowanego obrazu ewolucji i zmiany ewolucyjnej. ${ }^{19} \mathrm{~W}$ takim sformułowaniu koncepcja ta mówi o występowaniu sprzężenia zwrotnego i interakcjach na wielu poziomach przyczynowych, ze szczególnym naciskiem na zachowanie organizmów jako głównej przyczynie modulującej reżimy selekcyjne. W świetle tej koncepcji dwustronnej przyczynowości aktywność organizmów jest ujęta w związkach wzajemnego wpływu oraz środowisk rozwojowych i ewolucyjnych za pośrednictwem wymiany troficznej, wydzielania i ruchu. Mówiąc bardziej sugestywnie, jest to obraz, w którym „rozwijające się organizmy nie są wyłącznie wytworami, ale też przyczynami ewolucji”. ${ }^{20} \mathrm{Z}$ punktu widzenia optymistów radykalne konsekwencje teoretyczne tego bardziej rzeczowego sformułowania koncepcji dwustronnej przyczynowości rzucają się w oczy w przypadku procesów tworzenia nisz, zwłaszcza tam, gdzie aktywności populacji generują systematyczne zmiany w rozwojowych i selekcyjnych środowiskach kolejnych pokoleń. ${ }^{21}$

\footnotetext{
${ }^{18}$ Por. James Woodward, Making Things Happen: A Theory of Causal Explanation, Oxford University Press, Oxford 2003.

${ }^{19}$ Por. Laland, Sterelny, Odling-Smee, Hoppitt, and Uller, „Cause and Effect in Biology Revisited...”; Laland, Uller, Feldman, Sterelny, Müller et al., „The Extended Evolutionary Synthesis..."; Watson, Mills, Buckley, Kouvaris, Jackson, Powers, Cox, Tudge, Davies, Kounios, and Power, „Evolutionary Connectionism...”; Laland, Odling-Smee, and Endler, „Niche Construction, Sources of Selection and Trait Coevolution...".

${ }^{20}$ Laland, Uller, Feldman, Sterelny, Müller et al., „The Extended Evolutionary Synthesis...”, s. 6.

${ }^{21}$ Por. John Odling-Smee, Kevin N. Laland, and Marcus W. Feldman, Niche Construction: The Neglected Process in Evolution, Princeton University Press, Princeton 2003.
} 
Aby być sprawiedliwym, należy zauważyć, że badacze uczestniczący w powszechnej praktyce znają to bardziej rzeczowe sformułowanie koncepcji dwustronnej przyczynowości. Skutki wywoływane przez organizmy na reżimy selekcyjne są szczególnie wyraźne w ramach ekologii ewolucyjnej, czego przykładem są intensywne empiryczne i teoretyczne prace dotyczące dynamiki drapieżnik-ofiara, wpływów rodzicielskich i ewolucji społecznej. W związku z tym przyznanie eksplanacyjnej wartości bardziej rzeczowemu sformułowaniu koncepcji dwustronnej przyczynowości nie musi wymuszać dalszej zmiany metodologicznej i pojęciowej. W gruncie rzeczy sceptycy twierdzą, że tworzenie nisz jest najczęściej przedstawiane — i być może najlepiej pojmowane - w sposób deflacyjny. To deflacjonistyczne ujęcie traktuje prace na temat tworzenia nisz jako próbę modelowania pewnego zakresu nowych dynamik selekcyjnych, nie zaś jako radykalne wyzwanie dla powszechnej praktyki. ${ }^{22}$

Niemniej optymiści EES uważają, że rzeczowy pogląd na dwustronną przyczynowość wspiera ich twierdzenia na temat rozbudowanej i rozszerzonej powszechnej praktyki. Podstawą tego ich argumentu nie jest wyłącznie koncepcja dwustronnej przyczynowości, ale też idiosynkratyczne pojmowanie historii i organizacji teorii ewolucji. Jest to widoczne wówczas, gdy optymiści EES charakteryzują pewne założenie przyjmowane w ramach powszechnej praktyki przy tworzeniu modeli. Założenie to nazywają frakcjonowaniem. ${ }^{23}$

Frakcjonowanie to strategia reprezentowania i modelowania dynamiki ewolucyjnej, w której zakłada się, że składowe procesy ewolucyjne działają autonomicznie. Słowo „autonomiczny” oznacza tutaj, że przyczyny leżące u podłoża zmian ewolucyjnych rozwój i przetrwanie, replikacja i dziedziczenie oraz tworzenie nowych cech i zmienność - stanowią odrębne dziedziny aktywności przyczynowej, a związki przyczynowe między nimi są zaniedbywalne. Na przykład w takim ujęciu ewolucji procesy zaangażowane w generowanie mutacji i innowacji (między innymi błędy w kopiowaniu lub rekombinacja chromosomów) nie wpływają bezpośrednio na maszynerię rozwojową, która tworzy fenotypy. Mutacje jedynie przekształcają przenoszące informację nośniki genetyczne, które ulegają translacji za pomocą takiej maszynerii rozwojowej.

Frakcjonowanie to strategia epistemiczna, w świetle której ewolucja zachodzi w szeregu nieoddziałujących ze sobą kroków. Dlatego frakcjonowanie nie różni się od innych założeń, które przyjmowane są w ramach teorii ewolucji przy tworzeniu modeli,

\footnotetext{
${ }^{22}$ Por. np. Wray, Hoekstra, Futuyma, Lenski, Mackay et al., „Does Evolutionary Theory Need a Rethink..."

${ }^{23}$ Por. Denis M. Walsh, Organisms, Agency, and Evolution, Cambridge University Press, Cambridge 2015; Uller and Helanterä, „Niche Construction and Conceptual Change in Evolutionary Biology...".
} 
na przykład od założenia o nieskończonej wielkości populacji przyjmowanego w wielu modelach genetyki populacyjnej. Kiedy jednak uwzględni się czynnik czasu, strategie reprezentacyjne mogą stać się tak obwarowane, że alternatywy wydają się trudne do wyobrażenia. Strategie zaczynają mieć wówczas charakter podstawowy, być może nawet ontologiczny. W gruncie rzeczy twierdzenie to ma zasadnicze znaczenie dla dokonanej przez Denisa Walsha ${ }^{24}$ historycznej rekonstrukcji współczesnej teorii ewolucji: na przestrzeni dwudziestego wieku założenia frakcjonowania tak bardzo się scementowały w powszechnej praktyce, że nie są już traktowane jako założenia, lecz jako prawdziwe reprezentacje procesów ewolucyjnych.

Stanowisko Walsha jest kontrowersyjne, a przeanalizowałem je w innej publikacji. ${ }^{25}$ Mimo to, nawet gdybyśmy mieli uznać słuszność argumentu Walsha, wciąż można by mieć sceptyczne podejście co do jego zakresu: wygląda na to, że frakcjonowanie nie jest charakterystyczną strategią w dużej części ewolucyjnej biologii rozwoju, genetyki ilościowej lub ekologii. Strategia ta jest stosowana przede wszystkim w poszczególnych strategiach modelowania $\mathrm{w}$ dziedzinach ekologii behawioralnej i genetyki populacyjnej. ${ }^{26}$ Warto więc zastanowić się, jakie mogą być ogólniejsze konsekwencje koncepcji dwustronnej przyczynowości. W końcu, jeśli koncepcja dwustronnej przyczynowości jest przeciwstawna strategii frakcjonowania, a ta ostatnia stanowi wyłącznie mały podzbiór metod biologii ewolucyjnej, to większy gmach EES jest najwyraźniej wzniesiony na chwiejnym fundamencie.

W tym miejscu optymiści EES przyjmują charakterystyczną strategię: sugerują, że frakcjonowanie w istocie charakteryzuje dużą część powszechnej praktyki. Jest tak dlatego, że genetyka populacyjna tworzy jądro powszechnej praktyki w ramach teorii ewolucji. Łącząc ze sobą pewien zakres źródeł historycznych, optymiści konstruują scenariusz historyczny, zgodnie z którym genetyka populacyjna odegrała główną rolę w powstaniu „Nowoczesnej Syntezy”. Twierdzą, że genetyka populacyjna nadal stanowi ogólną ramę teoretyczną.

Zasugerowałem wcześniej, że jedną z ważnych linii podziału między optymistami EES a sceptykami jest stopień, w jakim według nich nowe badania wymagają odnowienia jądra powszechnej praktyki. Optymiści twierdzą, że takie zmiany właśnie się zaczynają lub zachodzą już od jakiegoś czasu, natomiast sceptycy zaprzeczają temu, by badania EES znacząco zmieniały powszechną praktykę. Historyczny scenariusz optymi-

\footnotetext{
${ }^{24}$ Por. Walsh, Organisms, Agency, and Evolution....

${ }^{25}$ Por. Andrew Buskell and Adrian CurRIE, „Forces, Friction, and Fractionation: Denis Walsh's Organisms, Agency, and Evolution", Biology \& Philosophy 2017, vol. 32, no. 6, s. 1341-1353; Welch, "What's Wrong with Evolutionary Biology...".

${ }^{26}$ Por. WeLch, „What's Wrong with Evolutionary Biology...”.
} 
stów ma w istocie na celu zarówno zidentyfikowanie jądra powszechnej praktyki — założeń frakcjonowania $\mathrm{w}$ genetyce populacyjnej - jak i zaprezentowanie wiarygodnych, empirycznie płodnych alternatyw.

Argumenty te są jednak dyskusyjne. Po pierwsze, nie jest jasne, w jakiej mierze powszechna praktyka jest lub była scentralizowana wokół modeli, teorii i założeń genetyki populacyjnej. Na przykład Alan Love przyjmuje podejście erotetyczne i argumentuje, że teoria ewolucji może być eklektycznie zorganizowana wokół specyficznych dla danej dyscypliny pytań badawczych. Po drugie, dyskusyjny jest również scenariusz historyczny EES. Historycy, filozofowie i biologowie ewolucyjni zgodnie krytykują scenariusze postulujące, że doszło do jednego zdarzenia — tej jedynej Nowoczesnej Syntezy - które zdominowane było przez formalne modele matematyczne genetyki populacyjnej. ${ }^{27}$

Mimo wszystko, nawet jeśli ten historyczny scenariusz jest wątpliwy, samo to, że optymiści EES argumentują przeciwko strategii frakcjonowania, nie jest równoznaczne $\mathrm{z}$ argumentowaniem przeciwko dominującym założeniom $\mathrm{w}$ teoriach i modelach $\mathrm{w}$ obrębie ważnych obszarów badań ewolucyjnych. W tej więc mierze, w jakiej ich argumenty na rzecz zmian teoretycznych i metodologicznych są przekonujące, wciąż mogą one stanowić bodziec do zmiany sposobu, w jaki w powszechnej praktyce ewolucję się pojmuje, przedstawia i prowadzi rozważania teoretyczne na jej temat. Jeśli organizmy wchodzą w nieustanne interakcje ze światem i biorą udział w złożonych sieciach wzajemnego wpływu przyczynowego - być może tworząc regularności środowiskowe w świecie, które mogą „przestawić” utajone przełączniki rozwojowe ${ }^{28}$ - to przyjmowane $\mathrm{w}$ ramach powszechnej praktyki założenia na temat przyczyn można podać w wątpliwość.

Wszystko więc wskazuje na to, że pozytywna epistemiczna wartość koncepcji dwustronnej przyczynowości powiązana jest z tym, w jak dużym stopniu udaje jej się

\footnotetext{
${ }^{27}$ Być może scenariusz najbardziej przystający do historycznego ujęcia optymistów przedstawił William Provine (por. William B. Provine, The Origins of Theoretical Population Genetics, University of Chicago Press, Chicago 1971), choć sam Provine przeczył tezie, że genetyka populacyjna odgrywa główną rolę w teorii ewolucji (por. np. William B. Provine, „Epilogue”, w: Ernst Mayr and William B. Provine (eds.), The Evolutionary Synthesis: Perspectives on the Unification of Biology, Harvard University Press, Cambridge 1980, s. 399-411). Inni historycy również krytykowali idee, że doszło do jednego zdarzenia, które można określić mianem tej jedynej Nowoczesnej Syntezy (por. np. Vassiliki B. SMocovitis, Unifying Biology: The Evolutionary Synthesis and Evolutionary Biology, Princeton University Press, Princeton 1996; Joe CaIN, „Rethinking the Synthesis Period in Evolutionary Studies”, Journal of the History of Biology 2009, vol. 42, no. 4, s. 621-648; Erika L. Milam, „The Equally Wonderful Field: Ernst Mayr and Organismic Biology”, Historical Studies in the Natural Sciences 2010, vol. 40, no. 3, s. 279317).

${ }^{28}$ Por. Mary Jane West-Eberhard, Developmental Plasticity and Evolution, Oxford University Press, Oxford 2003.
} 
wykazać istnienie złożonych sieci wzajemnego wpływu. Może to obejmować identyfikowanie nowych rodzajów dwustronnych związków przyczynowych, dostarczanie nowych narzędzi empirycznych lub pokazywanie, że w ramach powszechnej praktyki nie przedstawia się kluczowych cech przyczynowych zmian ewolucyjnych. Najistotniejszym wyzwaniem dla zwolenników EES jest jednak wyartykułowanie, jak dokładnie dwustronna przyczynowość ułatwia lub uwidocznia taki wzajemny wpływ przyczynowy. Podczas gdy zwolennicy EES sugerują, że koncepcja dwustronnej przyczynowości stanowi część pakietu idei, które „prowadzą do czegoś więcej niż tylko do uprawiania nauki «tak jak zwykle»: wymagają one zmiany pojęciowej”, ${ }^{29}$ wysuwane są również twierdzenia temu przeczące. Osoby najbliższe temu, co nazywam stanowiskiem „sceptycznym", utrzymują, że koncepcja dwustronnej przyczynowości jest powszechnie stosowana w ramach powszechnej praktyki, a więc przyjęcie tej koncepcji nie wymaga wprowadzenia żadnych radykalnych zmian pojęciowych lub teoretycznych. ${ }^{30}$ Gdzieś między tymi dwoma stanowiskami znajdują się badacze argumentujący, że chociaż koncepcja dwustronnej przyczynowości dodaje pewne zasoby pojęciowe do teorii ewolucji, to jedynie ułatwiają one tworzenie nowych narzędzi empirycznych i dopiero te dodatkowe narzędzia mogą ewentualnie rzucić wyzwanie powszechnej praktyce. ${ }^{31} \mathrm{Te}$ różne interpretacje uzmysławiają, że koncepcja dwustronnej przyczynowości jest niejednoznaczna i ma potencjalne zastosowanie do wielu odmiennych celów.

Sugeruję tutaj, że można zidentyfikować trzy wiarygodne linie argumentacji na rzecz pozytywnej epistemicznej wartości koncepcji dwustronnej przyczynowości. Te strategie różnią się w interpretacji tego, jakie koncepcja dwustronnej przyczynowości wnosi pojęciowe, teoretyczne i empiryczne zasoby, które mają znaczenie dla rozumienia złożonych sieci interakcji przyczynowych, $\mathrm{i}$ - w konsekwencji — tego, jak ta koncepcja ma podważyć powszechną praktykę ewolucjonistyczną. Te trzy linie argumentacji to:

Empiryczna trafność: dwustronna przyczynowość jest powszechna pośród przyczyn, które leżą u podstaw zjawisk ewolucyjnych, a modele, w których uwzględnia się dwustronną przyczynowość, z większym prawdopodobieństwem będą empirycznie trafne w badaniu przynajmniej niektórych aspektów tych zjawisk;

${ }^{29}$ Laland, Uller, Feldman, Sterelny, Müller et al., „The Extended Evolutionary Synthesis...”, s. 10.

${ }^{30}$ Por. Dickins and Barton, ,Reciprocal Causation and the Proximate-Ultimate Distinction...”; Douglas J. Futuyma, Evolutionary Biology Today and the Call for an Extended Synthesis”, Interface Focus 2017, vol. 7, numer artykułu: 20160145, https://doi.org/10.1098/rsfs.2016.0145; Svensson, „On Reciprocal Causation in the Evolutionary Process...".

${ }^{31}$ Por. Martínez and Esposito, „Multilevel Causation and the Extended Synthesis...”; Watson, Mills, Buckley, Kouvaris, Jackson, Powers, Cox, Tudge, Davies, Kounios, and Power, „Evolutionary Connectionism...". 
Wzmocnienie systemu: dwustronna przyczynowość częściowo wyjaśnia stabilne naciski selekcyjne, uwydatniając rolę odgórnych ograniczeń rozwojowych i behawioralnych;

Zachowanie otwartości umyslu: koncepcja dwustronnej przyczynowości zapewnia ujęcie przyczynowe, które może przeciwdziałać podstępnym praktykom ograniczającym moc teorii ewolucji.

Jak zasugerowałem powyżej, te argumenty wymagają w pewnej mierze interpretacji i ekstrapolacji. W dalszej części artykułu rozważę więc kilka możliwych sposobów, w jakie koncepcja dwustronnej przyczynowości może dać pozytywny wkład do badań ewolucyjnych. Identyfikując i artykułując te linie argumentacji, wskażę również na punkty, w których sceptycy mogą podważać (lub już podważają) twierdzenia EES.

\section{Empiryczna trafność}

Koncepcja dwustronnej przyczynowości nie jest czymś nowym w biologii. Związki przyczynowe między kluczowymi procesami ewolucyjnymi znane są z badań dotyczących doboru płciowego, konfliktu między rodzicami a potomstwem, doboru zależnego od częstości oraz doboru zależnego od gęstości. W każdym z tych przypadków wartości parametrów lub cech osobników tego samego gatunku (na przykład preferencji samic) mogą zarówno wpływać na i znajdować się pod wpływem parametrów lub cech innych osobników tego samego gatunku (na przykład pokazy samców). Do tych przykładów osobników tego samego gatunku można dodać wiele międzygatunkowych zjawisk koewolucyjnych, w tym mutualizm, wtapianie się w otoczenie, mimikrę i zasadę Czerwonej Królowej. Optymiści EES znajdują się więc w doborowym towarzystwie, kiedy twierdzą, że „dwustronna przyczynowość stanowi typową, a być może nawet uniwersalną cechę ewoluujących i rozwijających się układów”. ${ }^{32}$ Założenie dotyczące wszechobecności dwustronnej przyczynowości jest już obecne w powszechnej praktyce ewolucjonistycznej.

Jeśli to uwzględnimy, to dość zaskakujące wydaje się twierdzenie, że podejście do nauk o życiu wymaga zmiany, czy że z powodu swojej powszechności „dwustronną przyczynowość należy teraz postrzegać jako normę, a nie wyjątek". ${ }^{33}$ Takie spostrzeżenia domagają się zinterpretowania.

W świetle pewnej słabej interpretacji twierdzenie to byłoby hipotezą empiryczną na

\footnotetext{
${ }^{32}$ Laland, Uller, Feldman, Sterelny, Müller et al., „The Extended Evolutionary Synthesis...”, s. 7.

${ }^{33}$ Laland, Odling-Smee, Hoppitt, and Uller, ,More on How and Why: Cause and Effect in Biology Revisited...", s. 738 .
} 
temat powszechności dwustronnej przyczynowości w przyrodzie ożywionej, ale nie przyjmowano by założenia, że ma ona teoretyczne lub metodologiczne implikacje. Takie stanowisko najprawdopodobniej zajmuje na przykład Erik Svensson, ${ }^{34}$ który sugeruje, że koncepcja dwustronnej przyczynowości zwraca naszą uwagę na złożoność zjawisk ewolucyjnych oraz na potrzebę większej współpracy między badaczami. Jest to jedna z możliwych interpretacji roli dwustronnej przyczynowości, ale optymiści EES zdają się sądzić, że ma ona szersze konsekwencje. Zaczyna się je dostrzegać, kiedy utrzymuje się nie tylko, że dwustronna przyczynowość występuje powszechnie, ale też, że niektóre ważne ewolucyjne procesy przyczynowe muszą być modelowane przy uwzględnieniu tego rodzaju przyczynowości. Stanowisko to implikuje kolejne twierdzenie - że w ramach aktualnej powszechnej praktyki nie tworzy się takich modeli lub nie dysponuje się zasobami, które to umożliwiają. Taka interpretacja koncepcji dwustronnej przyczynowości prowadzi do pewnego empirycznego zagadnienia: czy istnieją takie rodzaje zjawisk ewolucyjnych, które wymagają zbadania lub przynajmniej byłyby lepiej badane, gdyby proces ewolucji ujmowano w kategoriach dwustronnej przyczynowości?

Możemy potraktować to pytanie jako problem empirycznej trafności: czy koncepcja dwustronnej przyczynowości umożliwia postęp w kierunku osiągnięcia celów badań? Innymi słowy, empiryczna trafność to związek między zasobami badacza a tworzeniem epistemicznych dóbr (chodzi na przykład o formułowanie wyjaśnień, zdoby wanie wiedzy czy artykułowanie teorii). Takie dobra tworzone są przy realizacji tego, co Ingo Brigandt i Alan Love nazywają ,programami problemowymi” lub „eksplanacyjnymi”. Są to pytania badawcze, które ustanawiają cele badań empirycznych i nadają im strukturę. ${ }^{35}$ Argumentują oni, że to, co zostanie uznane za satysfakcjonującą produkcję dóbr, będzie określane i udoskonalane w miarę postępu badań: badania empiryczne ujawniają ,założenia na temat tego, co należy rozumieć przez tworzenie adekwatnej ramy eksplanacyjnej”. ${ }^{36}$ Określanie empirycznej trafności koncepcji dwustronnej przyczynowości nie polega jedynie na ocenie jej roli w opracowywaniu empirycznych metod i narzędzi w codziennych badaniach, ale także jej udziału w strukturyzacji badań i kierowaniu nimi w całej społeczności badaczy.

Zrozumienie, że koncepcja dwustronnej przyczynowości może odgrywać tę podwójną rolę — w tworzeniu narzędzi empirycznych i strukturyzacji badań empirycznych — może pomóc wyjaśnić skądinąd zagadkową strategię optymistów EES, którzy

\footnotetext{
${ }^{34}$ Por. Svensson, „On Reciprocal Causation in the Evolutionary Process...”.

${ }^{35}$ Por. Ingo BRIGANDT and Alan C. Love, „Evolutionary Novelty and the Evo-Devo Synthesis: Field Notes”, Evolutionary Biology 2010, vol. 37, no. 2, s. 93-99.

${ }^{36}$ Brigandt and Love, „Evolutionary Novelty and the Evo-Devo Synthesis...”, s. 96.
} 
usiłują wprowadzić zmiany do powszechnej praktyki na podstawie powszechnego konsensusu dotyczącego faktów empirycznych.

Powyżej pokazałem, że dwustronna przyczynowość jest powszechnie uznawana za ważne zjawisko $\mathrm{w}$ wielu domenach genetyki populacyjnej, ekologii i biologii rozwoju. Co ciekawe, panuje też powszechna zgoda co do tego, że zjawiska dwustronnej przyczynowości, które optymiści EES traktują jako podstawowe dla ich ujęcia - chodzi przynajmniej o tworzenie nisz, dziedziczenie inkluzyjne, plastyczność fenotypową i tendencyjność rozwojową - są rzeczywiste. Niemniej to, czy te zjawiska powinny być głównym przedmiotem badań ewolucyjnych, to zupełnie inna sprawa. Zespół Lalanda sugeruje, że w ramach powszechnej praktyki ,stale ujmuje się te zjawiska w sposób umniejszający ich istotność". ${ }^{37} \mathrm{~W}$ odpowiedzi zespół Wraya argumentuje jednak, że ,żadne ze zjawisk wskazywanych przez zespół Lalanda nie jest ignorowane w biologii ewolucyjnej [...] znaczenie tych czterech zjawisk w dyskursie współczesnej teorii ewolucji stanowi odzwierciedlenie ich potwierdzonej mocy eksplanacyjnej, nie zaś ich lekceważenia". ${ }^{38}$ Uznanie, że ta debata dotyczy wartości badań oraz ogólniejszej teoretycznej i empirycznej istotności — nie zaś teoretycznej i empirycznej zasadności pomaga wyjaśnić, co jest tutaj stawką.

Niemniej badacze EES sądzą, że proponowane przez nich ujęcie dostarcza również nowych narzędzi empirycznych i hipotez. Pozytywne ich zalety, jak zasugerowałem, są związane z ich zdolnością do ujawniania złożonych sieci wzajemnego wpływu na wielu poziomach. Czy coś świadczy o tym, że koncepcja dwustronnej przyczynowości pomaga tworzyć takie narzędzia? Chociaż EES wskazuje na szeroki zakres zjawisk podlegających dwustronnej przyczynowości - i być może potwierdzających tę koncepcję ${ }^{39}$ — to duża część tych ustaleń poprzedza pojęciowe i teoretyczne innowacje EES. Nie jest więc jasne, czy i w jakiej mierze EES lub koncepcja dwustronnej przyczynowości są kluczowe dla tych empirycznych przedsięwzięć. Mimo to uważam, że istnieją dwa przykłady, które potwierdzają tezę, że koncepcja dwustronnej przyczynowości rzeczywiście dostarcza nowych zasobów pojęciowych tworzących nowe rodzaje narzędzi dla badaczy i określających nowe linie badań.

Pierwszego przykładu dostarczają Tobias Uller i Heikki Helanterä, ${ }^{40}$ którzy argu-

\footnotetext{
${ }^{37}$ Laland, Uller, Feldman, Sterelny, Müller et al., „Does Evolutionary Theory Need a Rethink...”, s. 164.

${ }^{38}$ Wray, Hoekstra, Futuyma, Lenski, Mackay et al., „Does Evolutionary Theory Need a Rethink...”, s. 163.

${ }^{39}$ Por. Laland, Uller, Feldman, Sterelny, Müller et al., „The Extended Evolutionary Synthesis...”.

${ }^{40}$ Por. Uller and Helanterä, „Niche Construction and Conceptual Change in Evolutionary Biology...".
} 
mentują, że różne modele i koncepcje tworzenia nisz są odpowiedniejsze do badania ewoluowalności. Tutaj ewoluowalność rozumiana jest jako możliwe trajektorie, którymi mogą podążyć populacje w pewnej abstrakcyjnej, wielowymiarowej przestrzeni cech. ${ }^{41}$ Podstawą rozumowania Ullera i Helanterä jest kontrastowy charakter wyjaśnień przyczynowych. Dlaczego na przykład modliszki storczykowe wyglądają jak ten storczyk, a nie inny? W odpowiedzi sugerują oni, że zważywszy na wiedzę o zasobach rozwojowych, elastyczności behawioralnej i zasobach środowiskowych w przypadku danej populacji, koncepcja dwustronnej przyczynowości zapewnia dodatkowe zasoby, aby można było rozważyć szerszy zakres kontrastowych sytuacji eksplanacyjnych szczególnie tych, w których aktywność organizmów zmienia warunki rozwoju.

Ich studium przypadku stanowi myszak plażowy (Peromyscus polionotus). Wyniki wcześniejszych badań ujawniły, że pewien jednonukleotydowy polimorfizm moduluje kolor sierści tych myszy i pomaga unikać drapieżników dzięki selekcjonowaniu myszy o jaśniejszej sierści na jasnych, piaszczystych plażach, a myszy o ciemniejszej sierści na terenach leżących w głębi lądu. ${ }^{42}$ Uller i Helanterä przekonują jednak, że ten scenariusz o podłożu genowym nie wskazuje na jedyną trajektorię ewolucyjną, którą mogły obrać populacje myszy plażowej. Dzięki koncepcji dwustronnej przyczynowości można dostrzec szerszy zakres możliwości ewolucyjnych. Badacze skupiają się na scharakteryzowaniu tworzenia nisz rozwojowych, gdzie systematyczne zmiany w pokoleniu rodzicielskim mogą strukturyzować zasoby rozwojowe pokoleń potomnych. Sugerują oni, że takie systematyczne zmiany mogły obejmować zmiany w zachowaniach dotyczących kopania nor i we wrażliwości na sygnały o ataku drapieżników z powietrza, czy też skłaniające myszy do poszukiwania nowych terenów. Co ważne, część tych kontrfaktycznych trajektorii zależna jest od roli społecznego uczenia się, kiedy behawioralne strategie pokolenia rodzicielskiego wpływają na ekspozycję na bodźce i afektywne ich wartościowe przez pokolenie potomne.

Przykład podany przez Ullera i Helanterä jest spekulatywny, ale opiera się na bogatej literaturze na temat wpływów rodzicielskich, transmisji społecznej i tworzenia nisz. Jeśli mają rację, to w ramach powszechnej praktyki rzeczywiście lekceważy się pewne rodzaje kontrastowych sytuacji eksplanacyjnych - zwłaszcza te dotyczące wpływów międzypokoleniowych, które kształtują plastyczne zdolności organizmów. Koncepcja dwustronnej przyczynowości może więc odgrywać ważną rolę w zwracaniu uwagi na te słabo zbadane zjawiska ewolucyjne i dostarczaniu ich teoretycznych modeli.

\footnotetext{
${ }^{41}$ Por. też Rachael L. Brown, „What Evolvability Really Is”, The British Journal for the Philosophy of Science 2014, vol. 65, no. 3, s. 549-572.

${ }^{42}$ Por. Hopi E. Hoekstra, Rachel J. Hirschmann, Richard A. Bundey, Paul A. Insel, and Janet P. Crossland, „A Single Amino Acid Mutation Contributes to Adaptive Beach Mice Color Pattern”, Science 2006, vol. 313, no. 5783, s. 101-104.
} 
Istnieją jednak powody, by wątpić w to, że takie kontrastowe sytuacje eksplanacyjne rzeczywiście są ignorowane. Na gruncie ekologii istnieje bogata literatura na temat plastycznych reakcji populacji i osobników na zmieniające się warunki środowiska. ${ }^{43}$ Co więcej, w literaturze tej znajduje się szeroki zakres subtelne rozgraniczonych scenariuszy, w tym scenariusze mówiące o zmianach „przełącznikowych” wywoływanych przez reakcje progowe, ${ }^{44}$ stopniowych zmianach opartych na ciagłej zmienności, ${ }^{45}$ oraz zmiennej ekspresji temporalnej, takiej jak sezonowy polifenizm. ${ }^{46}$ Dla naszych obecnych celów najważniejsze jest chyba to, że dysponujemy coraz większym korpusem prac empirycznych i teoretycznych badających koszty wyewoluowania samej plastyczności i jej możliwego wpływu na zrozumienie długoterminowych trendów ewolucyjnych. ${ }^{47}$ Kiedy więc przychodzi zrozumieć rolę plastyczności w wywoływaniu zmian ewolucyjnych — nawet zmian na przestrzeni jednego lub kilku pokoleń — nie jest jasne, czy koncepcja dwustronnej przyczynowości jest kluczowa dla zidentyfikowania niedostrzeżonych lub niedoreprezentowanych kontrastowych sytuacji eksplanacyjnych.

Rozważmy jednak drugi przykład zaczerpnięty z prac zespołu Watsona, ${ }^{48}$ który posłużył się analogią między teorią ewolucji a teorią uczenia się — zwłaszcza między

${ }^{43}$ Por. Carl D. Schlicting and Massimo Pigliucci, Phenotypic Evolution: A Reaction Norm Perspective, Sinauer Associates, Sunderland 1998; West-EвеRHARd, Developmental Plasticity and Evolution...; Thomas J. DeWitt and Samuel M. Scheiner, Phenotypic Plasticity: Functional and Conceptual Approaches, Oxford University Press, Oxford 2004.

${ }^{44}$ Por. np. Curtis M. Lively, „Predator-Induced Shell Dimorphism in the Acord Barnacle Chthamalus anisopoma", Evolution 1986, vol. 40, no. 2, s. 232-242.

${ }^{45}$ Por. np. Nancy M. Schoeppner and Rick A. RelyeA, „Detecting Small Environmental Differences: Risk-Response Curves for Predator-Induced Behavior and Morphology”, Oecologia 2008, vol. 154, no. 4, s. 743-754.

${ }^{46}$ Por. np. Paul M. Brakefield and W. Anthony Frankino, „Polyphenisms in Lepidoptera: Multidisciplinary Approaches to Studies of Evolution and Development", w: Douglas W. Whitman and T.N. Ananthakrishnan (eds.), Phenotypic Plasticity in Insects: Mechanisms and Consequences, CRC Press, Enfield 2009, s. 337-368.

${ }^{47}$ Por. Courtney J. Murren, J.R. Auld, Hilary Callahan, Cameron K. Ghalambor, Corey A. HandelsMAN et al., „Constraints on the Evolution of Phenotypic Plasticity: Limits and Costs of Phenotype and Plasticity", Heredity 2015, vol. 115, no. 4, s. 293-301.

${ }^{48}$ Por. Richard A. Watson, Günter P. Wagner, Mihaela Pavlicev, Daniel M. Weinreich, and Rob Mills, „The Evolution of Phenotypic Correlations and «Developmental Memory»”, Evolution 2014, vol. 68, no. 4, s. 1124-1138; Richard A. Watson and Eörs SzATHMÁry, „How Can Evolution Learn?”, Trends in Ecology and Evolution 2016, vol. 31, no. 2, s. 147-157; Kostas Kouvaris, Jeff Clune, Loizos Kounios, Markus BredE, Richard A. Watson, „How Evolution Learns to Generalise: Using the Principles of Learning Theory to Understand the Evolution of Developmental Organization", PLoS Computational Biology 2017, vol. 13, no. 4, numer artykułu: e1005358, https://doi.org/10.1371/journ al.pcbi.1005358. 
sieciami genów a sieciami neuronowymi. ${ }^{49}$ Budując na bogatym korpusie formalnych rozważań teoretycznych, zespół Watsona sugeruje, że narzędzia i metody zaczerpnięte $\mathrm{z}$ teorii uczenia się rzucają dodatkowe światło na wiele ważnych teoretycznych i filozoficznych zagadnień teorii ewolucji, w tym na wielkie przejścia w aspekcie odrębności, dynamikę ekosystemów, ewolucję architektury genomowej i — co intrygujące - na zdolność doboru naturalnego do uogólniania i ,antycypowania” przyszłych środowisk selekcyjnych.

Antycypacja i uogólnianie są cechami znanymi z literatury na temat architektury sieci. ${ }^{50}$ Po wytrenowaniu w odniesieniu do pewnego zbioru bodźców sieci potrafią uogólnić je na podobne bodźce — zdolność ta nazywana jest „ekstrakcją sygnału” lub „prototypu”. Na przykład po zapoznaniu się ze zbiorem nietypowych psów — dajmy na to mało znanych ras, jak puli lub Lagotto romagnolo - sieć koneksyjna potrafiłaby rozpoznać i skategoryzować bardziej znane rasy (labradory, teriery i tym podobne). Zespół Watsona sugeruje, że ewolucja jest w stanie uzyskać podobną zdolność na wielu poziomach przyczynowych. Ewolucja może wychwytywać „głębokie regularności” strukturalne grupy właściwości — które ułatwiają reakcje adaptacyjne w wielu skalach czasowych i przestrzennych. W ten sposób ewolucja może dokonywać uogólnień na nowe, choć strukturalnie podobne, środowiska selekcyjne. Badacze wskazują na to, że „ewolucja pozyskuje więc informację z przeszłych zdarzeń selekcyjnych w ten sam zasadniczy sposób, jak proste systemy uczenia się pozyskują informację z przeszłego doświadczenia". 5

Koncepcja dwustronnej przyczynowości ma dla tego scenariusza kluczowe znaczenie, ponieważ zapewnia sposób ulepszenia parametrów zmian ewolucyjnych (selekcji, zmienności i dziedziczności), które nakładają ograniczenia na odwzorowania między sieciami a zachowaniem. Te dwustronne związki uznawane są za rodzaj dwustronnych zjawisk przyczynowych wskazywanych przez optymistów EES, takich jak tendencyjność rozwojowa, tworzenie nisz i dziedziczenie inkluzyjne, jak również zjawisk wskazywanych przez zespół Watsona, takich jak wielkie przejścia w aspekcie odrębności ${ }^{52}$ i dynamika ekosystemów. ${ }^{53}$ Zjawiska te cechuje sprzężenie zwrotne między różnymi poziomami przyczynowości tworzącymi „korelacje lub kowariancje między składnika-

${ }^{49}$ Por. Jirí Vohradsky, „Neural Model of the Genetic Network”, Journal of Biological Chemistry 2001, vol. 276, no. 39, s. 36168-36173; Jirí Vohradsky, „Neural Network Model of Gene Expression”, Federation of American Societes for Experimental Biology Journal 2001, vol. 15, s. 846-854.

${ }^{50}$ Por. Andy CLark, Associative Engines: Connectionism, Concepts, and Representational Change, MIT Press, Cambridge 1993.

${ }^{51}$ Watson and Szathmáry, „How Can Evolution Learn...”, s. 148.

${ }^{52}$ Por. John Maynard Smith and Eörs Szathmáry, The Major Transitions in Evolution, W.H. Freeman, Oxford 1995 
mi, które wcześniej były niezależne". ${ }^{54} \mathrm{Na}$ przykład to, co nazywają interakcjami „EvoDevo”, obejmuje związki przyczynowe między sieciami regulatorowymi genów a parametrami środowiskowymi, które wspólnie są w stanie modyfikować rozkład zmienności fenotypowej. Natomiast „EvoEco” decyduje o tym, jak kumulatywne interakcje między społecznościami organizmów modyfikują naciski selekcyjne, a „EvoEgo" określa, jak interakcje między bytami na różnych poziomach przekształcają i zmieniają mechanizmy dziedziczenia.

Podsumowując, jednym ze sposobów, w jakie optymiści wydają się argumentować na rzecz wartości koncepcji dwustronnej przyczynowości i — ogólniej rzecz biorąc ujęcia EES, jest położenie nacisku na empiryczną trafność. Mam jednak nadzieję, że wykazałem, iż zwolennicy EES argumentują na rzecz takiej trafności, biorąc za podstawę powszechną akceptację istnienia i znaczenia wielu zjawisk ewolucyjnych. Do tej pory w debacie między optymistami a sceptykami niewiele wskazuje na to, że koncepcja dwustronnej przyczynowości ujawnia nowe kontrastowe sytuacje eksplanacyjne, nieodkryte jeszcze przez biologów ewolucyjnych. Mimo to koncepcja ta może odegrać główną rolę w inspirowaniu nowych kierunków badań, w których istotne znaczenie mają wzajemnie wpływające na siebie związki przyczynowe na wielu poziomach. Wspomniałem tutaj o badaniach zespołu Watsona, ale równie dobrze mógłbym odnieść się do ekscytujących modeli z dziedziny teorii grafów i systemów dynamicznych, dotyczących wpływów sieci genetycznych. ${ }^{55}$ Krótko mówiąc, chociaż koncepcja dwustronnej przyczynowości może nie identyfikować lub wyodrębniać „nowych” bądź „lekceważonych" zjawisk ewolucyjnych, to być może już odgrywa pewną rolę w strukturyzowaniu toczących się badań pod kątem fundamentalnych pytań na temat ewolucji.

\section{Wzmocnienie systemu}

Jedna z interesujących hipotez empirycznych proponowanych przez optymistów EES dotyczy tego, jak złożona sieć interakcji przyczynowych obejmujących sprzężenie wprzód i sprzężenie zwrotne, które cechują zjawiska biologiczne, może stanowić ostateczną podstawę dla modeli opracowywanych w ramach powszechnej praktyki. Zespół Kevina Lalanda sugeruje, że empiryczny sukces standardowych modeli ewolucyjnych

\footnotetext{
${ }^{53}$ Por. Christopher H. Lean, „Indexically Structured Ecological Communities”, Philosophy of Science 2018 , vol. 85 , no. 3 , s. 501-522.

${ }^{54}$ Watson and Szathmáry, „How Can Evolution Learn...”, s. 153.

${ }^{55}$ Por. np. Isaac SAlazar-Ciudad, „On the Origins of Morphological Disparity and Its Diverse Developmental Bases", BioEssays 2006, vol. 28, no. 11, s. 1112-1122; Johannes JAEGER, David IRONS, and Nick Monk, „The Inheritance of Process: A Dynamical Systems Approach”, Journal of Experimental Zoology Part B: Molecular and Developmental Evolution 2012, vol. 318, no. 8, s. 591-612.
} 
może dojść do skutku na podstawie leżącej u ich podłoża koncepcji dwustronnej przyczynowości. ${ }^{56}$ Oznacza to, że koncepcja dwustronnej przyczynowości wyjaśnia, dlaczego sprawdzają się modele wykorzystujące strategię frakcjonowania i wskazujące na jednokierunkową przyczynowość:

Świat zewnętrzny jest najprawdopodobniej kapryśny, ale z perspektywy ewoluujących organizmów liczy się środowisko selekcyjne i jeśli to środowisko zachowuje pewną stałość na przestrzeni pokoleń (lub zmienia się w przewidywalne sposoby), to indukcyjne ryzyko jest z większym prawdopodobieństwem opłacalne. Oznacza to, że oczekiwalibyśmy, iż organizmy odnoszące sukces w procesie ewolucji będą skutecznie przekształcać swoje środowisko selekcyjne w przewidywalne sposoby [...] jak gdyby w odpowiedni sposób „obciążały kostki do gry" i przewidywały rezultat rzutu nimi. ${ }^{5}$

Tutaj organizmy, które „przekształcają swoje środowisko selekcyjne”, to te zaangażowane $\mathrm{w}$ dwustronny proces przyczynowy.

W moim przekonaniu argumentacja ta przebiega w sposób następujący: (1) różnice w stopniu przystosowania cech stanowią odzwierciedlenie związku między cechami a środowiskami; (2) jeśli stopnie przystosowania poszczególnych cech nie są (w pewniej mierze) stabilne w czasie, to nie może nastąpić ukierunkowana i kumulatywna selekcja; (3) kluczowymi elementami, które zapewniają stabilność nacisków selekcyjnych w czasie, są aktywności samych organizmów oraz (4) takie aktywności organizmów najlepiej jest opisywać w kategoriach dwustronnej przyczynowości. W związku $\mathrm{z}$ tym $\mathrm{w}$ tej mierze, $\mathrm{w}$ jakiej modele opracowywane $\mathrm{w}$ ramach powszechnej praktyki zakładają względnie stabilne naciski selekcyjne, milcząco odwołują się do stabilizującego wpływu aktywności organizmów.

Jest to treściwe twierdzenie empiryczne. Zespół Lalanda argumentuje na jego rzecz, wskazując na pewien zakres funkcji „buforowania”, mianowicie na „zapobiegawczą" aktywność termitów, ptaków i ssaków, która polega na tworzeniu nisz. ${ }^{58}$ Być może najjaśniejszym przykładem tego, co nazywają oni „zapobiegawczym tworzeniem nisz", jest budowanie termitier przez termity. ${ }^{59}$ Termity z rodzaju Macrotermes budują duże, złożone struktury z odrębnymi komorami przeznaczonymi do gromadzenia poży-

\footnotetext{
${ }^{56}$ Por. Laland, Odling-Smee, Hoppitt, and Uller, „More on How and Why: Cause and Effect in Biology Revisited...”.

${ }^{57}$ Laland, Odling-Smee, Hoppitt, and Uller, ,More on How and Why: Cause and Effect in Biology Revisited...", s. 739-740.

${ }^{58}$ Por. Laland, Odling-Smee, Hoppitt, and Uller, „More on How and Why: Cause and Effect in Biology Revisited...", s. 739.

${ }^{59}$ Por. J. Scott Turner, The Extended Organism: The Physiology of Animal-Built Structures, Harvard University Press, Cambridge 2000.
} 
wienia, rozmnażania się i tak dalej. Niezwykły w przypadku tych struktur jest sposób, w jaki są one nieustannie przekształcane i zmieniane tak, aby utrzymywać odpowiednie warunki do życia. W obliczu dużej zmienności warunków klimatycznych kolonie tych termitów potrafią modyfikować strukturę termitiery w celu regulowania cyrkulacji tlenu, dwutlenku węgla, a nawet temperatury kolonii.

Podobne argumenty wysuwane są w ramach ewolucyjnej biologii rozwoju. Marc Kirschner i John Gerhart argumentowali, że strukturalne cechy rozwijających się organizmów - mianowicie zespoły modułowych, rozpoznawczych i słabo regulowanych procesów - ułatwiają zmiany genetyczne w trakcie trwania ewolucji (termin „ułatwiać" znaczy tutaj tyle, co umożliwiać). ${ }^{60}$ Jest tak dlatego, że te strukturalne cechy gwarantują, że organizmy zostaną utworzone $\mathrm{z}$ dostateczną odpornością, redundancją i plastycznością, by przystosowywać się do zmienności wielu elementów. Taka zmienność nieustannie podlega testowaniu ze względu na zdolność do utrzymania się, co odbywa się po części za pośrednictwem interakcji ze środowiskiem. W tym ujęciu zmienność generowana, kumulowana i wyrażana jest w sposób wrażliwy na funkcjonowanie organizmów. Zadaniem selekcjonowania zmian jest więc wyłącznie stabilizowanie cech organizmów.

Podobnie jak w przypadku innych, omówionych powyżej argumentów EES, istnieją dwa sposoby interpretowania wysuniętych tutaj twierdzeń. Zgodnie ze słabą interpretacją strukturalne i behawioralne cechy pomagają utrzymywać organizm przy życiu. Jest to idea, w myśl której organizmy dokonują działań po to, aby „zwiększyć szanse na to, że [one] i ich potomstwo utrzymają się w swoich przestrzeniach tolerancji". ${ }^{6}$ W takim sformułowaniu ta słaba interpretacja jest oczywista. Organizmy angażują się przecież w szeroki zakres aktywności - pozyskiwanie pożywienia, wydalanie odpadów, walkę z patogenami — w celu zwiększenia swojej zdolności do życia oraz okazji do rozmnażania się.

W świetle mocniejszej interpretacji strukturalne cechy organizmów i pewne aspekty ich zachowania nakładają ograniczenia na zmiany, które są dostępne dla procesu selekcji. Ograniczenia oznaczają tutaj to samo, co „ułatwianie”: ograniczenia strukturyzują zmiany widoczne dla selekcji, ponieważ sprawiają, że niektóre zmiany są bardziej, a inne mniej prawdopodobne. Przy tej mocniejszej interpretacji zapobiegawcze tworzenie nisz i ułatwiona zmienność są przykładami ograniczeń generowanych przez procesy

\footnotetext{
${ }^{60}$ Por. Marc W. Kirschner and John C. Gerhart, The Plausibility of Life: Resolving Darwin's Dilemma, Yale University Press, New Haven 2005; John C. Gerhart and Marc W. KIrschner, „The Theory of Facilitated Variation”, Proceedings of the National Academy of Sciences USA 2007, vol. 104, Supplement 1, s. 8582-8589.

${ }^{61}$ Laland, Odling-Smee, Hoppitt, and Uller, „More on How and Why: Cause and Effect in Biology Revisited...", s. 739.
} 
dwustronnej przyczynowości. Wszystkie te przyczynowe interakcje — pomiędzy organizmami, ich częściami i ich środowiskami — „wzmacniają system”, aby wesprzeć zarówno stabilność selekcji, jak i sprawić, by pewne wyniki selekcji były bardziej prawdopodobne od innych.

Ograniczenia mogą stanowić element wyjaśnień ewoluowalności - dlaczego ewolucja pewnych populacji z większym prawdopodobieństwem prowadzi do określonych rezultatów niż ewolucja innych populacji — jak przekonaliśmy się wcześniej w przypadku prac zespołu Watsona. Selekcja może oddziaływać tylko na korzystne zmiany, a ograniczenia determinują, jakie rodzaje korzystnych wariantów będą dostępne. ${ }^{62}$ Próba zrozumienia trajektorii selekcyjnych rzeczywiście powinna obejmować rozważania o typowym zakresie wariantów, które dana populacja najprawdopodobniej utworzy, a także rozważania o tym, jak różne środowiska mogą wpływać na rozkład takich zmian. ${ }^{63}$ Nie należy jednak wyolbrzymiać zalet idei dotyczących stabilizacji i ograniczeń. Może być prawdą, że sposób, w jaki organizmy są tworzone i wchodzą w interakcje ze środowiskiem, ogranicza zarówno możliwe, jak i korzystne zmiany. $\mathrm{O}$ ile jednak ograniczenia nie mają charakteru deterministycznego, nie determinują one rezultatów, a tylko zmieniają prawdopodobieństwo wystąpienia określonych zmian. Nawet jeśli więc uznamy istnienie ograniczeń zmienności, otwarta pozostaje możliwość, że selekcja może odgrywać potężną rolę twórczą i ukierunkowującą. Jak argumentuje Tim Lewens, zarówno charakter ograniczeń i selekcji, jak i związki między nimi są złożone i wrażliwe na aktualne empiryczne potrzeby. ${ }^{64}$ Nigdy nie będziemy dysponować uniwersalnym ujęciem, w świetle którego dałoby się dokonywać oceny wpływu ograniczeń w porównaniu z wpływem selekcji.

Dlatego EES stanowi najnowszą powtórkę z debaty na temat związku między ograniczeniami a selekcją. ${ }^{65}$ Powyższe rozważania jasno wskazują na to, że według optymistów EES ograniczenia stanowią niedoceniony obszar badań. Sceptycy wciąż jednak — można dodać, że rozsądnie - sprzeciwiają się idei, że ograniczenia rozwojowe lub behawioralne odgrywają niepomierną rolę w kształtowaniu zmian widocznych dla se-

${ }^{62}$ Por. Tim Lewens, Organisms and Artifacts: Design in Nature and Elsewhere, MIT Press, Cambridge 2004 .

${ }^{63}$ Por. BRown, ,What Evolvability Really Is...”.

${ }^{64}$ Por. Lewens, Organisms and Artifacts...

${ }^{65}$ Por. Ron Amundson, „Two Concepts of Constraint: Adaptationism and the Challenge from Developmental Biology”, Philosophy of Science 1994, vol. 61, no. 4, s. 556-578; Isaac SAlazAR-Ciudad, „Developmental Constraints vs. Variational Properties: How Pattern Formation Can Help to Understand Evolution and Development", Journal of Experimental Zoology Part B: Molecular and Developmental Evolution 2006, vol. 306B, no. 2, s. 107-125. 
lekcji ${ }^{66}$ - co być może wymaga przyjęcia założenia, że takie ograniczenia są w równym stopniu obecne lub inwariantne w wielu typach organizmów bądź zdarzeniach selekcyjnych. ${ }^{67}$ Zagadnienia te coraz częściej stanowią przedmiot dociekań na przykład W ramach empirycznych badań ograniczeń wielkości mózgu ${ }^{68}$ i długości kończyn, ${ }^{69}$ jak również w wyrafinowanych badaniach symulacyjnych, testujących hipotezy optymalizacji. ${ }^{70}$ Autentyczne źródło niezgody między optymistami EES a sceptykami stanowi kwestia powszechności oraz znaczenia ograniczeń rozwojowych i behawioralnych. Oba obozy inaczej widzą sprawę istotności ograniczeń dla zmian ewolucyjnych, ale nie da się tego sporu rozstrzygnąć bez przeprowadzenia odpowiednich badań empirycznych.

\section{Zachowanie otwartości umysłu}

Optymiści EES utrzymują, że koncepcja dwustronnej przyczynowości zarówno motywuje teoretyczny i metodologiczny pluralizm, jak i że taki pluralizm jest coraz bardziej potrzebny w naukach biologicznych. ${ }^{71}$ Podstawą tego twierdzenia jest diagnoza, zgodnie z którą obecne badania ewolucyjne są w pewnym sensie ograniczone. Słowo „ograniczone” użyte jest tutaj jako termin specjalistyczny, który zwraca uwagę na to, w jaki sposób ramy teoretyczne sprawiają, iż dane empiryczne, pojęcia i metodologie są niewidoczne lub niedostępne w ramach powszechnej praktyki.

Ta ograniczona perspektywa przejawia się w niedostrzeganiu empirycznych i pojęciowych postulatów EES. Dotyczy to opisanych wcześniej zjawisk, a przynajmniej

\footnotetext{
${ }^{66}$ Por. Hopi E. Hoerstra and Jerry A. Coyne, „The Locus of Evolution: Evo Devo and the Genetics of Adaptation”, Evolution 2007, vol. 61, no. 5, s. 995-1016.

${ }^{67}$ Por. Lewens, Organisms and Artifacts...

${ }^{68}$ Por. Corina J. Logan, Shahar Avin, Neeltje Boogert, Andrew Buskell, Fiona R. Cross, Adrian Currie, Sarah Jelbert, Dieter Lukas, Rafael Mares, Ana F. Navarrete, Shuichi Shigeno, and Stephen H. Montgomery, „Beyond Brain Size: Uncovering the Neural Correlates of Behavioral and Cognitive Specialization”, Comparative Cognition \& Behavior Reviews 2018, vol. 13, s. 55-90.

${ }^{69}$ Por. Nathan M. Young, Günter P. Wagner, and Benedikt Hallgrimsson, „Development and the Evolvability of Human Limbs”, Proceedings of the National Academy of Sciences USA 2010, vol. 107, no. 8, s. 3400-3405.

${ }^{70}$ Por. Isaac Salazar-Ciudad and Miquel Marín-Riera, „Adaptive Dynamics under DevelopmentBased Genotype-Phenotype Maps", Nature 2013, vol. 497, s. 361-364

${ }^{71}$ Por. Laland, Sterelny, Odling-Smee, Hoppitt, and Uller, „Cause and Effect in Biology Revisited...”; Laland, Odling-Smee, Hoppitt, and Uller, „More on How and Why: Cause and Effect in Biology Revisited...”; Laland, Odling-Smee, Hoppitt, and Uller, „More on How and Why: A Response to Commentaries...”; Laland, Uller, Feldman, Sterelny, Müller et al., „Does Evolutionary Theory Need a Rethink...”; Laland, Uller, Feldman, Sterelny, Müller et al., „The Extended Evolutionary Synthesis...".
} 
tworzenia nisz, ograniczeń związanych z organizmami i ewoluowalności. Optymiści EES widzą $\mathrm{w}$ tym winę prowincjonalizmu dotyczącego założeń stabilizujących powszechną praktykę. Kluczowym tego typu założeniem jest ewolucyjny eksternalizm. Zgodnie $\mathrm{z}$ tym stanowiskiem organizmom powodzi się lepiej lub gorzej ze względu na sposób, w jaki dzięki swojej formie są w stanie radzić sobie z zewnętrznymi okolicznościami.

Ewolucyjny eksternalizm to styl badania „od zewnątrz do wewnątrz”. W myśl tego podejścia zrozumienie ewolucji organizmów i powodów, dla których mają one taką, a nie inną formę, wymaga wiedzy o środowiskach, które ukształtowały organizmy. Alternatywami dla eksternalizmu są internalizm i konstruktywizm. ${ }^{72}$ Internalizm tym różni się do eksternalizmu, że stanowi styl badania „od wewnątrz do zewnątrz”. W tym ujęciu ewolucja formy organizmów jest związana $z$ ograniczeniami, słabościami i kierunkowością narzuconymi przez same organizmy. Oba te podejścia różnią się od ewolucyjnego konstruktywizmu, w myśl którego organizm strukturyzuje lub współkonstytuuje swoje środowisko, co prowadzi do ewolucyjnej zmiany formy. ${ }^{73}$

Kiedy więc zwolennicy EES argumentują, że powszechna praktyka w obrębie teorii ewolucji jest ograniczona, chodzi im o to, że milcząco przyjmuje się w niej ewolucyjny eksternalizm. Jak jednak według nich dochodzi do takiej faworyzacji? Nie powinno zaskakiwać, że w ich przekonaniu problem dotyczy zagadnienia przyczynowości: „sposób, w jaki biologowie myślą o przyczynowości, działa jak metateoretyczna rama pojęciowa stabilizująca dominujący paradygmat naukowy". ${ }^{74}$ Optymiści EES argumentują, że z powodu tej metateoretycznej ramy pojęciowej alternatywne, internalistyczne praktyki badawcze (EvoDevo, DevoEvo) lub praktyki konstruktywistyczne (tworzenie nisz, koewolucja genów i kultury, EcoEvoDevo) były niesprawiedliwie marginalizowane. Jeśli na tym właśnie polega problem, to jakie jest jego rozwiązanie?

Metodologiczna rewizja, za którą opowiadają się optymiści EES, polega na tym, aby „nie wykluczać z góry żadnego potencjalnego wpływu przyczynowego”. ${ }^{75}$ Przekonują oni, że aby mogło do tego dojść, teoria ewolucji potrzebuje ramy pojęciowej, „która uwzględnia możliwość zachodzenia sprzężenia zwrotnego w obrębie dynamicznych cykli ewolucji kulturowej, koewolucji genów i kultury oraz koewolucji organizmów

\footnotetext{
${ }^{72}$ Por. Peter Godfrey-Smith, Complexity and the Function of Mind in Nature, Cambridge Studies in Philosophy and Biology, Cambridge University Press, Cambridge 1996.

${ }^{73}$ Por. Lewens, Organisms and Artifacts...; Walsh, Organisms, Agency, and Evolution....

${ }^{74}$ Laland, Odling-Smee, Hoppitt, and Uller, „More on How and Why: Cause and Effect in Biology Revisited...", s. 740

${ }^{75}$ Laland, Odling-Smee, Hoppitt, and Uller, „More on How and Why: Cause and Effect in Biology Revisited...”, s. 738.
} 
i środowiska". ${ }^{76}$ Według nich koncepcja dwustronnej przyczynowości może zapewnić podstawy dla takiej ramy pojęciowej.

Ta nowa rama pojęciowa nie pociąga za sobą, o ile jestem w stanie stwierdzić, całkowitego zastąpienia eksternalistycznych strategii badawczych przez strategie internalistyczne lub konstruktywistyczne. ${ }^{77}$ Badaniom eksternalistycznym należy po prostu nadać nową ramę pojęciową. Trzeba uznać, że takie badania są możliwe wyłącznie w wyjątkowych okolicznościach, to znaczy dotyczą one „szczególnego przypadku dwustronnej przyczynowości, kiedy sprzężenie zwrotne jest zaniedbywalne". ${ }^{78}$

Motywacją dla tych argumentów jest konkretna obawa. Jej przedmiot trudno jest jednak dostrzec. Aby lepiej go naświetlić, chciałbym przedstawić analogię do dobrze znanych argumentów Elisabeth Lloyd, które dotyczą roli adaptacjonistycznego rozumowania w ewolucjonistycznym sposobie myślenia. ${ }^{79}$

Z grubsza rzecz biorąc, adaptacjonizm to stanowisko, zgodnie z którym zdolność przystosowywania się lub pozorny, dobry projekt organizmów stanowi ważny, o ile nie najważniejszy, aspekt powszechnej praktyki w ramach teorii ewolucji. Co dokładnie znaczy tutaj słowo „ważny”, jest kwestią sporną, a komentatorzy zidentyfikowali i ocenili szereg stanowisk adaptacjonistycznych. ${ }^{80}$ Tutaj interesuje nas adaptacjonizm metodologiczny.

Adaptacjonizm metodologiczny może mieć mocniejszą i słabszą postać. Zważywszy na nasze obecne cele, rozważmy przedstawiony przez Elisabeth Lloyd obraz podstępnego adaptacjonizmu metodologicznego. ${ }^{81}$ Ten podstępny adaptacjonizm odgrywa

${ }^{76}$ Laland, Odling-Smee, Hoppitt, and Uller, „More on How and Why: Cause and Effect in Biology Revisited...", s. 737-738.

${ }^{77}$ Inni argumentowali, że nowa synteza powinna być silnie internalistyczna. Por. RoBert, Embryology, Epigenesis, and Evolution...; PIgliucCI and Müller, „Elements of an Extended Evolutionary Synthesis...".

${ }^{78}$ Laland, Odling-Smee, Hoppitt, and Uller, „More on How and Why: Cause and Effect in Biology Revisited...", s. 738.

${ }^{79}$ Por. Elisabeth A. LLoyd, The Case of the Female Orgasm: Bias in the Science of Evolution, Harvard University Press, Cambridge 2005; Elisabeth A. Lloyd, „Adaptationism and the Logic of Research Questions: How to Think Clearly about Evolutionary Causes", Biological Theory 2015, vol. 10, s. 343362.

${ }^{80}$ Por. Peter Godfrey-Smith, „On the Status and Explanatory Structure of Developmental Systems Theory”, w: Susan Oyama, Paul E. Griffiths, and Russell D. Gray (eds.), Cycles of Contingency: Developmental Systems and Evolution, Life and Mind: Philosophical Issues in Biology and Psychology, MIT Press, Cambridge 2001, s. 283-298; Tim Lewens, „Seven Types of Adaptationism”, Biology \& Philosophy 2009, vol. 24, no. 2, s. 161-182.

${ }^{81}$ Mimo że nazywam taki adaptacjonizm metodologiczny podstępnym, nie sugeruję istnienia jakiejś wielkiej konspiracji. Historycy i socjologowie nauki dawno już zauważyli, że reżimy nauczania (por. Tho- 
rolę w ustanawianiu celów badawczych i strukturyzowaniu badań poprzez określanie zasadności hipotez, ustalanie klas kontrastowych sytuacji eksplanacyjnych i regulowanie standardów dotyczących danych empirycznych. W ramach podstępnego adaptacjonizmu metodologicznego badania nastawione są na znalezienie adaptacyjnego charakteru cech i trwają dopóty, dopóki nie zostanie sformułowana najbardziej wiarygodna hipoteza adaptacjonistyczna. Inne ujęcia można wziąć pod rozwagę dopiero wtedy, kiedy żadna adaptacjonistyczna hipoteza nie uzyska odpowiedniego potwierdzenia. Jak argumentuje Lloyd, strategia pierwszeństwa dla hipotez adaptacjonistycznych marginalizuje inne wyjaśnienia, na przykład te, zgodnie z którymi rozpatrywane cechy są skutkiem egzaptacji, dryfu lub ograniczeń rozwojowych. Ta marginalizacja prowadzi do tego, że „hipotezę nieselekcjonistyczną często traktuje się jako porażkę próby odkrycia wyjaśnienia", ${ }^{82}$ nie zaś jako alternatywną hipotezę, którą warto rozważyć.

Kluczowym przykładem zastosowania podstępnego adaptacjonizmu metodologicznego, podanym przez Lloyd, jest ewolucja kobiecego orgazmu. ${ }^{83}$ Opowiada się ona za poglądem, że kobiecy orgazm stanowi produkt uboczny selekcji męskich orgazmów. Połączenia tkankowe i nerwowe, które umożliwiają kobiece orgazmy, są skutkiem struktur rozwojowych wspólnych wszystkim ludziom, ale powodem, dla którego takie struktury i szlaki rozwojowe $\mathrm{w}$ ogóle istnieją, jest fakt wcześniejszej ich selekcji u osobników męskich w jakimś punkcie odległej historii kladu ssaków. W tym ujęciu kobiecy orgazm jest zjawiskiem rzeczywistym pomimo tego, że nie pełni żadnej funkcji przystosowawczej — stanowi bowiem produkt uboczny selekcji męskich orgazmów.

Lloyd w przekonujący sposób wykazuje, że pomimo istnienia danych empirycznych przemawiających za poglądem, że kobiecy orgazm jest produktem ubocznym, podstępny adaptacjonizm metodologiczny marginalizuje takie dane i bagatelizuje ten pogląd. ${ }^{84}$ Chociaż jest to wiarygodna hipoteza ewolucjonistyczna i przemawiają za nią dane empiryczne, to „nie znajduje się ona na ich [adaptacjonistów metodologicznych]

mas S. Kunn, Struktura rewolucji naukowych, przeł. Helena Ostromęcka i Justyna Nowotniak, Fundacja Aletheia, Warszawa 2001), technologii (por. Robert E. KoнLеR, Lords of the Fly: Drosophila Genetics and the Experimental Life, University of Chicago Press, Chicago 1994), jak również sktruktur społecznych i stosunków władzy (por. Steven Shapin and Simon Schaffer, Leviathan and the Air-Pump: Hobbes, Boyle, and the Experimental Life, Princeton Classics, vol. 109, Princeton University Press, Princeton 1985) mogą prowadzić do utrwalenia pewnych celów i strategii badawczych, narzędzi oraz wyjaśnień kosztem innych. Mam na myśli właśnie ten przyziemny sens, zgodnie z którym na działalność naukową wpływają czynniki materialne, socjologiczne i polityczne.

${ }^{82}$ LLOYD, „Adaptationism and the Logic of Research Questions...”, s. 356.

${ }^{83}$ Por. Lloyd, The Case of the Female Orgasm....

${ }^{84}$ Por. Lloyd, „Adaptationism and the Logic of Research Questions...”, s. 351-359. 
liście możliwych odpowiedzi, która obejmuje wyłącznie takie odpowiedzi jak: «funkcją kobiecego orgazmu jest preferencyjne łączenie się w pary z najlepszymi mężczyznami» lub «funkcją kobiecego orgazmu jest ułatwianie łączenia się w pary» i tak dalej”. ${ }^{85}$

Przeprowadzona przez Lloyd analiza sposobu, w jaki adaptacjonizm metodologiczny deprecjonuje hipotezy nieselekcjonistyczne, jest subtelna i nie ma tutaj miejsca na zagłębianie się w jej szczegóły. Wystarczy powiedzieć, że Lloyd widzi winę w fałszywych dychotomiach eksplanacyjnych, braku „reguł mówiących, kiedy się zatrzymać”, niezdolności do uznania alternatywnych źródeł danych empirycznych i marginalizacji hipotez nieselekcjonistycznych, jako interesujących „hipotez zerowych”. Czynniki te umożliwiają utrwalenie podstępnego adaptacjonizmu metodologicznego i ze względu na nie w ramach powszechnej praktyki ignoruje się inne ważne źródła wyjaśnień.

Odnieśmy to teraz do koncepcji dwustronnej przyczynowości. W moim przekonaniu optymiści EES stosują argument $\mathrm{z}$ analogii. Argumentują mianowicie, że idea przyczynowości jednokierunkowej stanowi część wyjaśnienia dotyczącego podstępnego eksternalizmu metodologicznego, czyli ograniczonego pojmowania zjawisk ewolucyjnych, w ramach którego marginalizuje się alternatywy internalistyczne lub konstruktywistyczne. Oto, jak przebiega ta argumentacja. W biologii ewolucyjnej przyjmowane jest domyślne założenie, że cechy organizmów utrzymują się w populacjach dlatego, że rozwiązują problemy środowiskowe. To, dlaczego organizmy przeszły taką, a nie inną ewolucję, badacze wyjaśniają więc przez pryzmat wiedzy o dawnych środowiskach selekcyjnych. Ta strategia badawcza ignoruje jednak inne rodzaje kontrastowych sytuacji eksplanacyjnych, które uwzględniają rolę ograniczeń, architektury genomowej, tworzenia nisz i tym podobnych. Co więcej, ta strategia badawcza jest $\mathrm{w}$ istocie podstępna, ponieważ prowadzi do lekceważenia i marginalizacji alternatyw internalistycznych lub konstruktywistycznych.

Powyższa rekonstrukcja argumentacji optymistów EES pomaga nadać sens wielu ich twierdzeniom, na przykład wspomnianemu wcześniej twierdzeniu, że założenia przyczynowe „stabilizują” powszechną praktykę. Założenia przyczynowe mogą odgrywać taką rolę, o ile za ich sprawą badacze lekceważą lub ignorują alternatywne modele przyczynowe. Interpretacja ta nadaje też sens twierdzeniom zespołu Lalanda, że „to, czy dany proces opiszemy jako przybliżony, czy ostateczny, zależy bezwzględnie od ramy pojęciowej przyjętej przez badacza”. ${ }^{86}$ przy czym taka rama pojęciowa „ogranicza zbiór hipotez, które uznaje się za konkurencyjne". ${ }^{87}$

\footnotetext{
${ }^{85}$ LLOYD, „Adaptationism and the Logic of Research Questions...”, s. 358 [wyróżnienia w oryginale].

${ }^{86}$ Laland, Odling-Smee, Hoppitt, and Uller, „More on How and Why: Cause and Effect in Biology Revisited...”, s. 720.
} 
Rozważmy jakiś przypadek dwustronnej przyczynowości, na przykład budowanie tam przez bobry. Takie zachowanie istnieje z powodu wcześniejszych zdarzeń selekcyjnych: doszło do selekcji albo pierwotnej skłonności do budowania tam, albo plastycznych mechanizmów, które mogły później ulec kooptacji i zostać wykorzystane do wykształcenia umiejętności budowania tam. W obu tych przypadkach populacje bobrów zareagowały na warunki środowiskowe, a te osobniki, które przetrwały, miały genetyczną predyspozycję do tworzenia tam lub do nabycia tej umiejętności. Zauważmy, że zgodnie z tym scenariuszem koncepcja dwustronnej przyczynowości ma $\mathrm{w}$ teorii ewolucji ograniczoną rolę eksplanacyjną, opisuje bowiem związki przyczynowe mechanizmów przybliżonych, których dynamika stanowi wyraz utajonej zmienności genetycznej powstałej na skutek wcześniejszych zdarzeń selekcyjnych.

Taki scenariusz potwierdza ewolucyjny eksternalizm: mechanizmy przybliżone są jedynie rezultatem wcześniejszych przypadków eksternalistycznej selekcji. Ta strategia odnosi jednak sukces poprzez zignorowanie lub zbagatelizowanie alternatyw internalistycznych lub konstruktywistycznych. Ignoruje możliwość, że plastyczne mechanizmy mogły mieć kluczowe znaczenie zarówno dla powstania, jak i utrzymania się umiejętności budowania tam ze względu na udział tych mechanizmów w stworzeniu środowiska odpowiedniego dla możliwości budowania tam. Jest to, jak mogliby argumentować optymiści EES, przykład ograniczenia badań ewolucjonistycznych. Scenariusz ten neguje możliwość, że procesy dwustronnej przyczynowości, takie jak tworzenie nisz, odgrywają istotną rolę ewolucyjną, ponieważ reinterpretuje proces tworzenia nisz, uznając go po prostu za skutek wcześniejszych zdarzeń selekcyjnych. Podobnie jak istnieje podstępny adaptacjonizm metodologiczny, tak też możemy mówić o podstępnym ewolucyjnym eksternalizmie.

Jest to bardzo ważna linia argumentacji. Jej powodzenie wymaga jednak przyjęcia wielu spornych twierdzeń przez optymistów. Wskażę teraz punkty, w których sceptycy mogą zasadnie podważyć tę argumentację.

Po pierwsze, sceptycy mogą zasadnie wątpić w to, że podstępny eksternalizm jest tak ważny lub powszechny jak podstępny adaptacjonizm. Skrajni eksternaliści oczywiście istnieją. Za tym stanowiskiem jawnie opowiadał się na przykład George Williams, który twierdził, że „Adaptacja jest zawsze symetryczna, czyli organizmy adaptują się do swoich środowisk, a nie na odwrót". ${ }^{88} \mathrm{~W}$ jakiej jednak mierze poglądy Williamsa są reprezentatywne dla powszechnej praktyki? Prace w dziedzinach ekologii ewolucyjnej,

\footnotetext{
${ }^{87}$ Laland, Odling-Smee, Hoppitt, and Uller, „More on How and Why: Cause and Effect in Biology Revisited...", s. 729.

${ }^{88}$ George C. Williams, „Gaia, Nature Worship and Biocentric Fallacies”, Quarterly Review of Biology 1992, vol. 67, no. 4, s. 484 [479-486].
} 
ewolucyjnej biologii rozwoju i ekologicznej biologii ewolucyjnej zdają się świadczyć o tym, że we współczesnych naukach ewolucyjnych jest miejsce dla wyjaśnień internalistycznych i konstruktywistycznych. Coraz większe rozpowszechnienie prac badających architekturę sieci regulatorowych genów w procesie rozwoju — na przykład regulowanego przez geny homeotyczne rozwoju kończyn skorupiaków ${ }^{89}$ — wskazuje na to, że podstępny eksternalizm może nie być zakorzeniony w praktyce wszystkich biologów ewolucyjnych.

Takie zastrzeżenia można mnożyć. Powróćmy do rozważań nad obrazem powszechnej praktyki przedstawianym przez optymistów EES. Wyżej zauważyłem, że tacy optymiści zwykle prezentują scenariusz historyczny, zgodnie z którym współczesna powszechna praktyka jest zorganizowana wokół głównego jądra tworzonego przez modele i założenia genetyki populacyjnej. Zauważyłem jednak również, że wielu historyków, biologów ewolucyjnych i filozofów podchodzi do tego scenariusza sceptycznie: zarówno wobec wskazywanego w nim jednego zdarzenia, które można nazwać ta jedy$n q$ Nowoczesną Syntezą, jak i wobec twierdzenia, że jądrem, wokół którego się ono skupiło, były założenia i modele genetyki populacyjnej. Zwróciłem też uwagę na prace Alana Love'a, które sugerują, że badania w obrębie nauk o życiu można zorganizować w bardziej eklektyczny sposób. ${ }^{90}$

Łącznie rozważania te kładą nacisk na twierdzenie o tym, że na nauki ewolucyjne zostało nałożone pewne ograniczenie. Chociaż pewne obszary powszechnej praktyki mogą być nieprzychylne dla twierdzeń internalistycznych lub konstruktywistycznych, to nie musi być tak w innych obszarach. Nie powinno więc zaskakiwać, że założenia internalistyczne mają duże znaczenie w badaniach ewolucyjnej biologii rozwoju i pracach na temat sieci regulatorowych genów.

Jednakże to, że jedynie kilka osób ma tyle śmiałości, by otwarcie opowiedzieć się za skrajnie eksternalistycznymi poglądami, nie świadczy o tym, że takie poglądy występują rzadko. I samo to, że niektóre obszary badań ewolucyjnych są otwarte na stanowiska internalistyczne i konstruktywistyczne, nie oznacza, że dotyczy to wszystkich obszarów. Te argumenty sceptyczne pokazują jednak, że uzasadnienie twierdzenia optymistów EES o podstępnych założeniach wymaga wskazania wielu danych i przeprowadzenia rzetelnej analizy.

\footnotetext{
${ }^{89}$ Por. Arnaud Martin, Julia M. Serano, Erin Jarvis, Heather S. Bruce, Jennifer Wang, Ray Shagnik, Carryn A. Barker, Liam C. O’Connell, and Nipam H. Patel, „CRISPR/Cas9 Mutagenesis Reveals Versatile Roles of Hox Genes in Crustacean Limb Specification and Evolution”, Current Biology 2016, vol. 26, no. 1, s. 14-26.

${ }^{90}$ Por. Love, ,Rethinking the Structure of Evolutionary Theory for an Extended Synthesis...”; Love, „Theory Is as Theory Does...”.
} 
Niestety nie ma tutaj miejsca na przenalizowanie takich danych, chociaż Tobias Uller i Heikki Helanterä jasno pokazali, jaka logika może stanowić podstawę takiego podstępnego stanowiska. ${ }^{91} \mathrm{~A}$ jest to wymagające zadanie. Elisabeth Lloyd poświęciła całą książkę - w której dokonała przeglądu wszystkich ówczesnych ujęć - udokumentowaniu metodologicznych i empirycznych mankamentów badań empirycznych dotyczących kobiecego orgazmu. ${ }^{92}$ Wykazała ponadto, że te mankamenty można wiarygodnie przypisać założeniom przyjmowanym w takich koncepcjach jak adaptacjonizm, pogląd o wyjątkowości człowieka czy androcentryzm. Lloyd nie tylko dowiodła, że te problemy rzeczywiście istnieją, ale także wiele miejsca poświęciła wykazaniu, że ich podłożem są podstępne założenia. Podobny standard dowodowy powinien obowiązywać optymistów EES, którzy starają się uzasadnić swoje twierdzenie o panowaniu podstępnego eksternalizmu.

Chociaż więc za twierdzeniami optymistów EES przemawiają pewne racje, to twierdzenia te mają co najwyżej charakter zapewnień. Na tę chwilę zasadniczo wykazują oni, że założenia frakcjonowania i eksternalizmu nakazują preferować jedne typy kontrastowych sytuacji eksplanacyjnych nad innymi. Pokazują też, że takie założenia mogą z dużym prawdopodobieństwem prowadzić do przyjęcia podstępnej logiki. To jest już coś. Optymiści EES nie uzasadnili jednak jeszcze twierdzenia, że taka podstępna logika jest stosowana.

\section{Zakończenie}

W praktyce naukowej koncepcje mają wiele różnych zastosowań. Często mają bezpośredni udział w praktyce empirycznej, określając, które konkretne kategorie, mechanizmy lub procesy w świecie są istotne dla badaczy. Niemniej nawet jeśli koncepcje są głęboko związane z zastosowaniami empirycznymi, to jednocześnie pełnią też różne inne funkcje. Mogą ułatwiać wymianę myśli i współpracę, wyznaczać i wyróżniać społeczności podobnie myślących badaczy, nadawać strukturę badaniom, wskazywać ścieżki poszukiwań i zwracać naszą uwagę na nieznane lub słabo dostrzegane zjawiska. Celem mojego artykułu było pokazanie, że koncepcja dwustronnej przyczynowości odgrywa szeroki zakres ról i nie służy wyłącznie do identyfikowania wzajemnego wpływu między procesami. Sądzę, że udało mi się wyraźnie oddzielić od siebie różne linie argumentacji związane z EES. Mam nadzieję, że dzięki temu przyczynię się do rozpoczęcia bardziej produktywnego i użytecznego dialogu na temat współczesnych badań

\footnotetext{
${ }^{91}$ Por. Uller and Helanterë, „Niche Construction and Conceptual Change in Evolutionary Biology...".

${ }^{92}$ Por. Lloyd, The Case of the Female Orgasm....
} 
ewolucyjnych, a także do lepszego zrozumienia ważnych zagadnień, których te linie argumentacji dotyczą.

Oczywiście nie twierdzę, że doszedłem do definitywnych wniosków na temat charakteru koncepcji dwustronnej przyczynowości lub EES. Na chwilę obecną proponowana przez optymistów alternatywna wizja zmiany ewolucyjnej, jak również ich teoretyczne i pojęciowe narzędzia, wciąż są niesprecyzowane i niekompletne. Niemniej argumenty optymistów wymierzone są w wiele aspektów powszechnej praktyki. Co więcej, dotyczą one fundamentalnych zagadnień teorii ewolucji. Nawet jeśli powszechna praktyka nie ulegnie dużej zmianie w wyniku tych zabiegów, dyskusja na ten temat może okazać się owocna. A jeśli tak, to ogólniej pojęta pozytywna epistemiczna wartość EES może mieć związek z czymś więcej niż tylko z roszczeniami do zmodyfikowania, uaktualnienia i rozszerzenia teorii ewolucji. Jej wartość może polegać na ujawnieniu i przeanalizowaniu założeń od dawna przyjmowanych w powszechnej praktyce. Dzięki rozdzieleniu od siebie różnych argumentów dotyczących koncepcji dwustronnej przyczynowości mam nadzieję przyczynić się do rozpoczęcia takiej produktywnej dialektyki.

Otwarty dostęp. Artykuł ten jest udostępniony na warunkach Creative Commons Attribution 4.0 International License (http://creativecommons.org/licenses/by/4.0/), która pozwala na nieograniczony użytek, dystrybucję i kopiowanie na dowolnym nośniku pod warunkiem dokładnego wskazania autora(ów) oraz pierwotnego źródła, zamieszczenia linku do licencji Creative Commons oraz informacji o dokonaniu ewentualnych zmian.

\section{Andrew Buskell}

\section{Bibliografia}

Amundson Ron, „Two Concepts of Constraint: Adaptationism and the Challenge from Developmental Biology", Philosophy of Science 1994, vol. 61, no. 4, s. 556-578.

Brakefield Paul M. and Frankino W. Anthony, „Polyphenisms in Lepidoptera: Multidisciplinary Approaches to Studies of Evolution and Development", w: Whitman and Ananthakrishnan (eds.), Phenotypic Plasticity in Insects..., s. 337-368.

Brigandt Ingo and Love Alan C., „Evolutionary Novelty and the Evo-Devo Synthesis: Field Notes", Evolutionary Biology 2010, vol. 37, no. 2, s. 93-99.

Brown Rachael L., „What Evolvability Really Is”, The British Journal for the Philosophy of Science 2014, vol. 65 , no. 3, s. 549-572.

Buskell Andrew and Currie Adrian, „Forces, Friction, and Fractionation: Denis Walsh's Organisms, Agency, and Evolution”, Biology \& Philosophy 2017, vol. 32, no. 6, s. 1341-1353. 
CaIN Joe, ,Rethinking the Synthesis Period in Evolutionary Studies”, Journal of the History of Biology 2009, vol. 42, no. 4, s. 621-648.

CalcotT Brett, „Why How and Why Aren't Enough: More Problems with Mayr's Proximate-Ultimate Distinction", Biology \& Philosophy 2013, vol. 28, no. 5, s. 767-780.

Carroll Sean B., Endless Forms Most Beautiful: The New Science of Evo Devo, Norton, New York 2005.

CArroll Sean B., „Evo-Devo and an Expanding Evolutionary Synthesis: A Genetic Theory of Morphological Evolution", Cell 2008, vol. 134, no. 1, s. 25-36.

Charlesworth Deborah, Barton Nicholas H., and Charlesworth Brian, „The Sources of Adaptive Variation", Proceedings of the Royal Society B: Biological Sciences 2017, vol. 284, numer artykułu: 20162864.

Clark Andy, Associative Engines: Connectionism, Concepts, and Representational Change, MIT Press, Cambridge 1993.

DeWitt Thomas J. and Scheiner Samuel M., Phenotypic Plasticity: Functional and Conceptual Approaches, Oxford University Press, Oxford 2004.

Dickins Thomas E. and BARTON Robert A., „Reciprocal Causation and the Proximate-Ultimate Distinction", Biology \& Philosophy 2013, vol. 28, no. 5, s. 747-756.

Dickins Thomas E. and Rahman Qazi, „The Extended Evolutionary Synthesis and the Role of Soft Inheritance in Evolution", Proceedings of the Royal Society B: Biological Sciences 2012, vol. 279 , no. 1740, s. 2913-2921.

Feldman Marcus W., Odding-Smee John, Laland Kevin N., „Why Gupta et al. 's Critique of Niche Construction Theory Is Off Target", Journal of Genetics 2017, vol. 96, no. 3, s. 505-508.

Fuentes Agustin, „The Extended Evolutionary Synthesis, Ethnography, and the Human Niche: Toward an Integrated Anthropology", Current Anthropology 2016, vol. 57, Supplement 13, s. S13-S26.

FutuYma Douglas J., Evolutionary Biology Today and the Call for an Extended Synthesis", Interface Focus 2017, vol. 7, numer artykułu: 20160145, https://doi.org/10.1098/rsfs.2016.0145.

FutuYMa Douglas J. and KirkPatrick Mark, Evolution, 4th ed., Oxford University Press, Oxford 2017.

Gerhart John C. and Kirschner Marc W., „The Theory of Facilitated Variation”, Proceedings of the National Academy of Sciences USA 2007, vol. 104, Supplement 1, s. 8582-8589.

Godfrey-Smitr Peter, Complexity and the Function of Mind in Nature, Cambridge Studies in Philosophy and Biology, Cambridge University Press, Cambridge 1996.

Godfrey-Smitr Peter, „On the Status and Explanatory Structure of Developmental Systems Theory”, w: Oyama, Griffiths, and Gray (eds.), Cycles of Contingency..., s. 283-298.

Gould Stephen Jay, The Structure of Evolutionary Theory, Harvard University Press, Cambridge 2002. 
Griffiths Paul E. and Gray Russell D., „Developmental Systems and Evolutionary Explanation”, The Journal of Philosophy 1994, vol. 91, no. 6, s. 277-304.

Gupta Manan, Prasad N.G., Dey Sutirth, Joshi Amitabh, and Vidya T.N.C., „Niche Construction in Evolutionary Theory: The Construction of an Academic Niche?", Journal of Genetics 2017, vol. 96 , no. 3, s. 491-504.

Gupta Manan, Prasad N.G., Dey Sutirth, Joshi Amitabh, and Vidya T.N.C., „Feldman et al. Do Protest Too Much, We Think", Journal of Genetics 2017, vol. 96, no. 3, s. 509-511.

Hoekstra Hopi E. and Coyne Jerry A., „,The Locus of Evolution: Evo Devo and the Genetics of Adaptation", Evolution 2007, vol. 61, no. 5, s. 995-1016.

Hoekstra Hopi E., Hirschmann Rachel J., Bundey Richard A., Insel Paul A., and Crossland Janet P., „A Single Amino Acid Mutation Contributes to Adaptive Beach Mice Color Pattern”, Science 2006, vol. 313, no. 5783, s. 101-104.

Huneman Philippe and Walsh Denis (eds.), Challenging the Modern Synthesis: Adaptation, Development, and Inheritance, Oxford University Press, Oxford 2017.

JAEger Johannes, Irons David, and Monk Nick, „The Inheritance of Process: A Dynamical Systems Approach", Journal of Experimental Zoology Part B: Molecular and Developmental Evolution 2012, vol. 318, no. 8, s. 591-612.

Kirschner Marc W. and Gerhart John C., The Plausibility of Life: Resolving Darwin's Dilemma, Yale University Press, New Haven 2005.

KITCHER Philip, The Advancement of Science: Science Without Legend, Objectivity Without Illusions, Oxford University Press, Oxford 1993.

KoHLER Robert E., Lords of the Fly: Drosophila Genetics and the Experimental Life, University of Chicago Press, Chicago 1994.

Kouvaris Kostas, Clune Jeff, Kounios Loizos, Brede Markus, Watson Richard A., „How Evolution Learns to Generalise: Using the Principles of Learning Theory to Understand the Evolution of Developmental Organization", PLoS Computational Biology 2017, vol. 13, no. 4, numer artykułu: e1005358, https://doi.org/10.1371/journ al.pcbi.1005358.

KuHN Thomas S., Struktura rewolucji naukowych, przeł. Helena Ostromęcka i Justyna Nowotniak, Fundacja Aletheia, Warszawa 2001.

Laland Kevin N., „On Evolutionary Causes and Evolutionary Processes”, Behavioural Processes 2015, vol. 117, s. 97-104.

Laland Kevin N., Odling-Smee John, and Endler John, „Niche Construction, Sources of Selection and Trait Coevolution”, Interface Focus 2017, vol. 7, no. 5, numer artykułu: 20160147.

Laland Kevin N., Odling-Smee John, Hoppitt William, and Uller Tobias, „More on How and Why: Cause and Effect in Biology Revisited", Biology \& Philosophy 2013, vol. 28, no. 5, s. $719-745$.

Laland Kevin N., Odling-Smee John, Hoppitt William, and Uller Tobias, „More on How and Why: A Response to Commentaries”, Biology \& Philosophy 2013, vol. 28, no. 5, s. 793-810. 
Laland Kevin N., Sterelny Kim, Odling-Smee John, Hoppitt William, and Uller Tobias, „Cause and Effect in Biology Revisited: Is Mayr's Proximate-Ultimate Dichotomy Still Useful?", Science 2011, vol. 334, no. 6062, s. 1512-1516.

Laland Kevin N., Uller Tobias, Feldman Marcus W., Sterelny Kim, Müller Gerd B. et al., „Does Evolutionary Theory Need a Rethink? Yes, Urgently”, Nature 2014, vol. 514, s. 161-164.

Laland Kevin N., Uller Tobias, Feldman Marcus W., Sterelny Kim, Müller Gerd B. et al., „The Extended Evolutionary Synthesis: Its Structure, Assumptions and Predictions”, Proceedings of the Royal Society B: Biological Sciences 2015, vol. 282, no. 1813, numer artykułu: 20151019.

Lean Christopher H., „Indexically Structured Ecological Communities”, Philosophy of Science 2018, vol. 85, no. 3, s. 501-522.

Levins Richard and Lewontin Richard, The Dialectical Biologist, Harvard University Press, Cambridge 1985.

Lewens Tim, Cultural Evolution: Conceptual Challenges, Oxford University Press, Oxford 2015.

Lewens Tim, Organisms and Artifacts: Design in Nature and Elsewhere, MIT Press, Cambridge 2004.

Lewens Tim, „Seven Types of Adaptationism”, Biology \& Philosophy 2009, vol. 24, no. 2, s. 161-182.

Lively Curtis M., „Predator-Induced Shell Dimorphism in the Acord Barnacle Chthamalus anisopoma", Evolution 1986, vol. 40, no. 2, s. 232-242.

LLOYD Elisabeth A., „Adaptationism and the Logic of Research Questions: How to Think Clearly about Evolutionary Causes", Biological Theory 2015, vol. 10, s. 343-362.

Lloyd Elisabeth A., The Case of the Female Orgasm: Bias in the Science of Evolution, Harvard University Press, Cambridge 2005.

Logan Corina J., Avin Shahar, Boogert Neeltje, Buskell Andrew, Cross Fiona R., Currie Adrian, Jelbert Sarah, Lukas Dieter, Mares Rafael, Navarrete Ana F., Shigeno Shuichi, and Montgomery Stephen H., „Beyond Brain Size: Uncovering the Neural Correlates of Behavioral and Cognitive Specialization", Comparative Cognition \& Behavior Reviews 2018, vol. 13, s. 55-90.

Love Alan C., „Evo-Devo and the Structure of Evolutionary Theory”, w: HunEman and WALSH (eds.), Challenging the Modern Synthesis..., s. 159-187.

Love Alan C., „Rethinking the Structure of Evolutionary Theory for an Extended Synthesis”, w: Pigliucci and Müller (eds.), Evolution: The Extended Synthesis..., s. 403-442.

Love Alan C., „Theory Is as Theory Does: Scientific Practice and Theory Structure in Biology”, Biological Theory 2013, vol. 7, no. 4, s. 325-337.

Lu Qiaoying and Bourrat Pierrick, „The Evolutionary Gene and the Extended Evolutionary Synthesis", British Journal for the Philosophy of Science 2018, vol. 69, no. 3, s. 775-800. 
Martin Arnaud, Serano Julia M., Jarvis Erin, Bruce Heather S., Wang Jennifer, Shagnik Ray, Barker Carryn A., O’Connell Liam C., and Patel Nipam H., „CRISPR/Cas9 Mutagenesis Reveals Versatile Roles of Hox Genes in Crustacean Limb Specification and Evolution", Current Biology 2016, vol. 26, no. 1, s. 14-26.

Martínez Maximiliano and Esposito Maurizio, „Multilevel Causation and the Extended Synthesis", Biological Theory 2014, vol. 9, no. 2, s. 209-220.

Maynard Smith John and Szathmáry Eörs, The Major Transitions in Evolution, W.H. Freeman, Oxford 1995.

Mayr Ernst and Provine William B. (eds.), The Evolutionary Synthesis: Perspectives on the Unification of Biology, Harvard University Press, Cambridge 1980.

Mesoudi Alex, Blanchet Simon, Charmantier Anne, Danchin Étienne, Fogarty Laurel, Jablonka Eva, Laland Kevin N., Morgan Thomas J.H., Müller Gerd B., Odling-Smee F. John, and Pujol Benoît, „Is Non-Genetic Inheritance Just a Proximate Mechanism? A Corroboration of the Extended Evolutionary Synthesis", Biological Theory 2013, vol. 7, no. 3, s. 189-195.

Miram Erika L., „The Equally Wonderful Field: Ernst Mayr and Organismic Biology”, Historical Studies in the Natural Sciences 2010, vol. 40, no. 3, s. 279-317.

MüLLER Gerd B., „Dlaczego rozszerzona synteza ewolucyjna jest niezbędna”, przeł. Dariusz Sagan, Filozoficzne Aspekty Genezy 2018, t. 15, s. 371-413, http://www.nauka-a-religia.uz.zgora. pl/images/FAG/2018.t.15/art.08.pdf [14.09.2020].

MüLler Gerd B., „Evo-Devo: Extending the Evolutionary Synthesis”, Nature Reviews Genetics 2007, vol. 8, no. 12 , s. 943-949.

Murren Courtney J., Auld J.R., Callahan Hilary, Ghalambor Cameron K., Handelsman Corey A. et al., „Constraints on the Evolution of Phenotypic Plasticity: Limits and Costs of Phenotype and Plasticity", Heredity 2015, vol. 115, no. 4, s. 293-301.

Oduing-Smee John, Laland Kevin N., and Feldman Marcus W., Niche Construction: The Neglected Process in Evolution, Princeton University Press, Princeton 2003.

Oyama Susan, The Ontogeny of Information: Developmental Systems and Evolution, Duke University Press, Durham 2000.

Oyama Susan, Griffiths Paul E., and Russell D. Gray (eds.), Cycles of Contingency: Developmental Systems and Evolution, Life and Mind: Philosophical Issues in Biology and Psychology, MIT Press, Cambridge 2001.

Pigliucci Massimo, „An Extended Synthesis for Evolutionary Biology”, Annals of the New York Academy of Sciences 2009, vol. 1168, s. 218-228.

Pigliucci Massimo, „Do We Need an Extended Evolutionary Synthesis?”, Evolution 2007, vol. 61 , no. 12 , s. $2743-2749$.

Pigliucci Massimo and Müller Gerd B., „Elements of an Extended Evolutionary Synthesis”, w: Pigliucci and Müller (eds.), Evolution: The Extended Synthesis..., s. 3-17.

Pigliucci Massimo and Müller Gerd B. (eds.), Evolution: The Extended Synthesis, MIT Press, Cambridge 2010. 
PIPERNo Dolores R., „Assessing Elements of an Extended Evolutionary Synthesis for Plant Domestication and Agricultural Origin Research", Proceedings of the National Academy of Sciences USA 2017, vol. 114, no. 25, s. 6429-6437.

Provine William B., „Epilogue”, w: Mayr and Provine (eds.), The Evolutionary Synthesis..., s. $399-411$.

Provine William B., The Origins of Theoretical Population Genetics, University of Chicago Press, Chicago 1971.

RafF Rudolf A., The Shape of Life: Genes, Development, and the Evolution of Animal Form, University of Chicago Press, Chicago 1996.

Robert Jason Scott, Embryology, Epigenesis, and Evolution: Taking Development Seriously, Cambridge University Press, Cambridge 2004.

Salazar-Ciudad Isaac, „Developmental Constraints vs. Variational Properties: How Pattern Formation Can Help to Understand Evolution and Development", Journal of Experimental Zoology Part B: Molecular and Developmental Evolution 2006, vol. 306B, no. 2, s. 107-125.

SAlazAR-Ciudad Isaac, „On the Origins of Morphological Disparity and Its Diverse Developmental Bases", BioEssays 2006, vol. 28, no. 11, s. 1112-1122.

Salazar-Ciudad Isaac and Marín-Riera Miquel, „Adaptive Dynamics under Development-Based Genotype-Phenotype Maps", Nature 2013, vol. 497, s. 361-364.

Schlicting Carl D. and Pigliucci Massimo, Phenotypic Evolution: A Reaction Norm Perspective, Sinauer Associates, Sunderland 1998.

Schoeppner Nancy M. and Relyea Rick A., „Detecting Small Environmental Differences: RiskResponse Curves for Predator-Induced Behavior and Morphology", Oecologia 2008, vol. 154, no. 4 , s. $743-754$.

Shapin Steven and Schaffer Simon, Leviathan and the Air-Pump: Hobbes, Boyle, and the Experimental Life, Princeton Classics, vol. 109, Princeton University Press, Princeton 1985.

Smocovitis Vassiliki B., Unifying Biology: The Evolutionary Synthesis and Evolutionary Biology, Princeton University Press, Princeton 1996.

Svensson Erik I., „On Reciprocal Causation in the Evolutionary Process”, Evolutionary Biology 2018, vol. 45 , no. 1 , s. 1-14.

Turner J. Scott, The Extended Organism: The Physiology of Animal-Built Structures, Harvard University Press, Cambridge 2000.

Uller Tobias and Helanterä Heikki, „Niche Construction and Conceptual Change in Evolutionary Biology", British Journal for the Philosophy of Science 2019, vol. 70, no. 2, s. 351-375.

Vohradsky Jirí, „Neural Model of the Genetic Network”, Journal of Biological Chemistry 2001, vol. 276, no. 39, s. 36168-36173.

Vohradsky Jirí, „Neural Network Model of Gene Expression”, Federation of American Societes for Experimental Biology Journal 2001, vol. 15, s. 846-854. 
Walsh Denis M., Organisms, Agency, and Evolution, Cambridge University Press, Cambridge 2015.

Watson Richard A., Mills Rob, Buckley C.L., Kouvaris Kostas, Jackson Adam, Powers Simon T., Cox Chris, Tudge Simon, Davies Adam, Kounios Loizos, and Power Daniel, „Evolutionary Connectionism: Algorithmic Principles Underlying the Evolution of Biological Organisation in Evo-Devo, Evo-Eco and Evolutionary Transitions”, Evolutionary Biology 2016, vol. 43, no. 4, s 553-581.

Watson Richard A., Wagner Günter P., Pavlicev Mihaela, Weinreich Daniel M., and Mills Rob, „The Evolution of Phenotypic Correlations and «Developmental Memory»”, Evolution 2014, vol. 68 , no. 4 , s. $1124-1138$

Watson Richard A. and Szathmáry Eörs, „How Can Evolution Learn?”, Trends in Ecology and Evolution 2016, vol. 31, no. 2, s. 147-157.

Welch John J., „What's Wrong with Evolutionary Biology?”, Biology \& Philosophy 2017, vol. 32 , no. 2 , s. 263-279.

West-Eberhard Mary Jane, Developmental Plasticity and Evolution, Oxford University Press, Oxford 2003.

Whitman Douglas W. and Ananthakrishnan T.N. (eds.), Phenotypic Plasticity in Insects: Mechanisms and Consequences, CRC Press, Enfield 2009.

Williams George C., „Gaia, Nature Worship and Biocentric Fallacies”, Quarterly Review of Biology 1992, vol. 67, no. 4, s. 479-486.

Woodward James, Making Things Happen: A Theory of Causal Explanation, Oxford University Press, Oxford 2003.

Wray Gregory A., Hoekstra Hopi E., Futuyma Douglas J., Lenski Richard E., Mackay Trudi F.C. et al., „Does Evolutionary Theory Need a Rethink? No, All Is Well”, Nature 2014, vol. 514, s. 161-164.

Young Nathan M., Wagner Günter P., and Hallgrímsson Benedikt, „Development and the Evolvability of Human Limbs", Proceedings of the National Academy of Sciences USA 2010, vol. 107, no. 8 , s. $3400-3405$.

Zeder Melinda A.,, „Domestication as a Model System for the Extended Evolutionary Synthesis", Interface Focus 2017, vol. 7, numer artykułu: 20160133, https://doi.org/10.1098/ rsfs.2016.0133.

\section{Dwustronna przyczynowość i rozszerzona synteza ewolucyjna}

\section{Streszczenie}

Zespół Kevina Lalanda przedstawił liczne argumenty przemawiające za rozszerzoną syntezą ewolucyjną. W tym artykule analizuję kluczową dla tych uczonych koncepcję dwustronnej przy czynowości. Koncepcja ta przywoływana jest w wielu argumentach na rzecz przyjęcia rozszerzonej ewolucjonistycznej ramy pojęciowej, niewielka część tych argumentów jest jednak jasno sprecyzowana. Objaśniam tutaj tę koncepcję i przedstawiam trzy linie argumentacji, w których 
jest ona wykorzystywana. Wskazuję na to, w których punktach sceptycy mogą podważać i podważają - te argumenty, jak również zwracam uwagę na główne, w moim przekonaniu, problemy empiryczne, eksplanacyjne i metodologiczne związane z tą koncepcją.

Slowa kluczowe: przyczynowość, teoria ewolucji, wyjaśnienie, rozszerzona synteza ewolucyjna.

\section{Reciprocal Causation and the Extended Evolutionary Synthesis}

\section{Summary}

Kevin Laland and colleagues have put forward a number of arguments motivating an extended evolutionary synthesis. Here I examine Laland et al.'s central concept of reciprocal causation. Reciprocal causation features in many arguments supporting an expanded evolutionary framework, yet few of these arguments are clearly delineated. Here I clarify the concept and make ex plicit three arguments in which it features. I identify where skeptics can - and are - pushing back against these arguments, and highlight what I see as the empirical, explanatory, and methodological issues at stake.

Keywords: causation, evolutionary theory, explanation, extended evolutionary synthesis. 